\title{
INCOME CONVERGENCE IN THE PROCESS OF THE WESTERN BALKAN STATES' ACCESSION TO THE EUROPEAN UNION
}

\author{
Nenad Stanisic* \\ Faculty of Economics, University of Kragujevac, Kragujevac, The Republic of Serbia
}

\begin{abstract}
One of the main expectations in European transition economies is that the processes of building the market economy and European integrations lead to a significant increase in the living standard, as well as to catching up with the level of the income per capita achieved in developed European economies. A quarter century after the beginning of transition, many of the former socialist countries joined the EU and significantly increased their GDP per capita. On the other hand, transition in the countries of the so-called Western Balkans has disappointed in this sense. The paper tests the existence and speed of income convergence in the Western Balkan states and developed EU countries, in comparison with the so-called „New Member States”. The results indicate that, despite the achieved income convergence in the pre-crisis years, the outbreak of the global economic crisis has revealed many structural and reform problems that the countries of the region have been facing for a long time. Catching up with developed EU members' average GDP per capita stopped in the Western Balkan states after the beginning of the crisis, with a simultaneous increase in the income gap between the Western Balkan states and the new EU member states.
\end{abstract}

Keywords: income convergence, economic development, the Western Balkans economies, European economic integrations

\section{JEL Classification: 047, P27, F43}

\section{INTRODUCTION}

Although economic transition towards capitalism and the market economy is accompanied by numerous problems in all European transition economies, it is particularly difficult and slow in the Western Balkans region (Croatia, Bosnia and Herzegovina, Montenegro,

\footnotetext{
* Correspondence to: N. Stanisic, Faculty of Economics, University of Kragujevac, Dj. Pucara 3, 34000 Kragujevac, The Republic of Serbia; e- mail: nstanisic@kg.ac.rs
}

the Republic of Serbia, FYR Macedonia, and Albania). Many Western Balkan states have spent a good part of the 1990s in devastating conflicts, of either international or internal nature, which delayed the start of the major transition reforms. After the "lost decade", the countries of the region began the new century in a politically stable environment, oriented towards economic development with the aim of increasing the living standard, which suffered a significant decline in the last decade of the twentieth century. What also 
became common to all the countries in the region is a strategic commitment to the European Union (EU) membership, due to which economic transition in the Western Balkans is inseparable from the process of European integrations, just as was the case in other European countries in transition.

In the past fifteen years, a significant economic progress has been achieved in the Western Balkan states (Murgasova, Ilahi, Miniane, Scott \& Vladkova-Hollar, 2015). All the countries initiated a transformation to market economies, privatized a large part of inefficient social and state-owned enterprises, reformed the banking system, opened up their economies to the European and other world markets, initiated significant infrastructure investments, and a reform of institutions and regulations. This resulted in an increase in the gross domestic product, the GDP per capita, and the income convergence of the countries of the region and the EU developed countries. However, the speed of the implementation of the reforms was insufficient and, even after fifteen years, the entire region is in a state of unfinished transition. Many reform tasks were not completed in a satisfactory manner. Privatization, the building of institutions and the legal system did not give the expected results. All these economic failures are reflected in a single indicator - still a very low level of the living standard, i.e. income per capita.

The subject of the research conducted in this paper is the income convergence of the Western Balkan states and the EU developed countries, i.e. the consideration of the tendencies to reduce the gap present in the economic development between the two groups of countries. The main objective of the research is to determine whether the countries of the region are on the way of catching up with the level of the EU living standards by analyzing the dynamics and trends in the change of the GDP per capita. In evaluating the performance of transition in the Western Balkans, the experience of transition countries that have completed the process of European integration by joining the EU during the first decade of the XXI century, the socalled "New Member States" (NMS), will also be taken into consideration. Therefore, an additional objective of the research is the one regarding the identifying of the differences (if any) in terms of the speed of income convergence between Western Balkan states (WBS) and the developed EU member states (EU-15), on the one hand, and the NMS and the EU-15, on the other.

In accordance with the aforementioned subject and objective of the research, the following research hypotheses are defined:

H1: The level of income in the Western Balkan states is approaching the level of income in the developed EU member states;

H2: The speed of the catching up with the average GDP per capita of the developed EU member states is equal in the Western Balkan states and the "new member states”.

Income convergence can be proved in two ways. According to the first approach, there is convergence if income dispersion among the countries in the observed group decreases over time (the so-called $\sigma$ convergence). According to the second approach, convergence exists if the economies that are initially located at the lower level of development grow faster than those that are more developed (the so-called $\beta$ convergence). Income convergence between the Western Balkan states and the developed EU member states will be tested in the paper using both of the above concepts.

The paper consists of the six sections. After the Introduction, the basic characteristics of the economic growth and an increase in the living standards of the Western Balkans region are analyzed. The third section presents the theoretical basis of income convergence and the results of the empirical research. The research methodology is explained in the fourth section, while the results of the research are presented in the fifth section of the paper. The last, sixth section summarizes the conclusions and defines the possible directions for further research.

\section{ECONOMIC GROWTH AND AN INCREASE IN THE LIVING STANDARD IN THE WESTERN BALKAN STATES}

The beginning of the last decade of the twentieth century in most of today's Western Balkan states was 
marked by an economic collapse, a sharp decline in economic activities and the living standards, all as a result of the conflicts and the creation of the new states in the former Socialist Federal Republic of Yugoslavia. The subsequent recovery had an uneven pace in the newly-created states, with a pronounced variability in the rate of economic growth. By the end of the 20th century, the GDP per capita reached the level of 1990. Although without conflicts, the beginning of transition in the region of Central Europe started with a recession.

Figure 1 shows the average annual growth rate of the real GDP in the period between 1993 and 2015, in the three sub-periods (1993-2000, 2001-2008, 2009-2015), for the three groups of states:

- the developed economies of the EU, the EU-15: Germany, France, Italy, Belgium, Netherlands, Luxembourg, United Kingdom, Denmark, Ireland, Greece, Portugal, Spain, Austria, Sweden, and Finland;

- the "New Member States" (NMS): Poland, the Czech Republic, Slovakia, Hungary, Slovenia, Lithuania, Latvia, Estonia, Romania, and Bulgaria; and

- the Western Balkan States (WBS): Croatia, Bosnia and Herzegovina, Montenegro, the Republic of Serbia, FYR Macedonia, and Albania.
Considering the difficulties in the initial stage of transition in almost all the countries, it is not surprising that in the last decade of the twentieth century the greatest economic growth was in the European Union states. The average annual growth rate of the real GDP in the period between 1993 and 2000 was the highest in the group of the EU-15 (3.8\%), while in the NMS group it was $2.9 \%$, and in the WBS group 3.0\% (Figure 1).

The new century brought transition countries a new momentum in economic growth. The countries of Central Europe and the Baltic region were coming closer to the moment of the entry into the EU and the Balkan states, clearly determined for the same route, initiated significant reforms. Generally speaking, the region of the Western Balkans in the period between 2001 and 2008 achieved significant results in the increase of income and the living standards, although not exactly as expected. With an average annual growth rate of the real GDP of $5.2 \%$, the Western Balkan states reduced the difference in development that existed between them and the EU-15 (the average annual growth rate of the real GDP in the same period was $2.3 \%$ in the EU-15). However, the achieved convergence was not entirely satisfactory because, in the group of NMS in the same period, a higher average growth rate of the real GDP of $5.7 \%$ was achieved. At a higher level of the GDP per capita in comparison to the WBS's, the indicated growth rate enabled the group of NMS to faster catch up with the income of the EU-

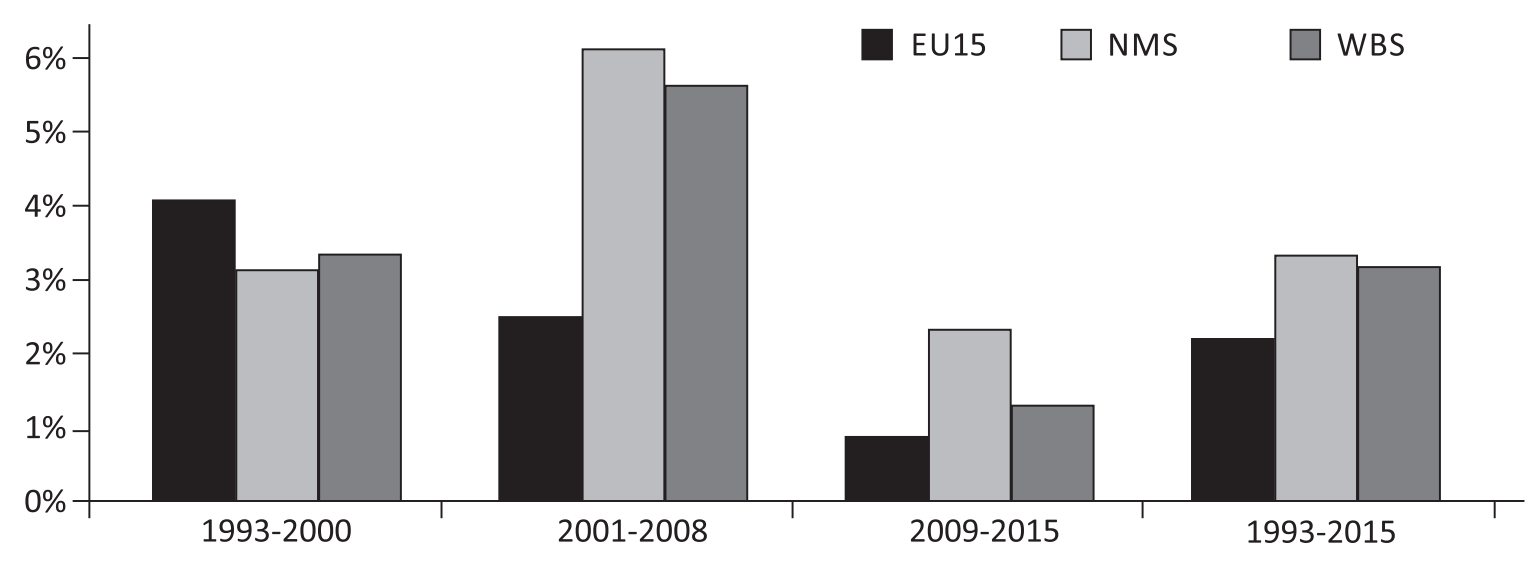

Figure 1 The average growth rate of the real GDP per capita in the EU-15, NMS, and WBS 
15. Then it was clear that transition in the Western Balkans region did not give the same results as it did in the other regions of Europe.

The process of the structural transformation of the Western Balkan economies was slowed in the mid2000s, and the poor reform solutions and even poorer results in certain segments of transition slowed down further economic progress. From that time to the outbreak of the global economic crisis in late 2008, economic growth in the Western Balkans region could be said to have been rather the result of the tendencies in the global economy, growing liquidity in the global capital market, a significant inflow of foreign capital, and a credit boom, than the result of real progress in the economic reforms (Murgasova et al, 2015). The clear evidence of the bad economic model in the Western Balkan states is an extremely high unemployment rate, exceeding $20 \%$, i.e. the incomplete use of the available human resources, even in the period of solid economic growth in the pre-crisis period. The difference in the pace and the manner of the implementation of the reforms among the NMS and the WBS is the main cause of the difference in the speed of the income convergence of the two groups of countries, according to the level of the developed EU countries.

The years of economic growth were interrupted in 2009 by the outbreak of the global economic crisis. Almost all European states recorded a decline in the economy. The post-crisis recovery was neither fast nor strong. Even in 2015, six years after the outbreak of the crisis, the European economy was not in an upswing. Among the EU states, the region of Central Europe was the first to overcome the crisis. The average annual growth rate of the real GDP in the NMS group was 2.2\% in the period between 2009 and 2015. During the same period, the growth rate in the EU-15 was $0.8 \%$, and in the WBS group - 1.2\%. The achieved growth rates brought the NMS region a new momentum in its catching up with the average income of the EU-15, and almost stagnation to the WBS region.

The years of the economic crisis removed the mask from the solid economic growth from the pre-crisis period in the Western Balkans and revealed all the shortcomings of the existing system, primarily the choice of the model of economic growth based on aggregate demand (i.e. domestic demand) and the political disorder and the economic policy conduct in terms of coalition governments (Prascevic, 2013). The global recession confirmed that economic growth was impossible without continuing structural changes. The studies indicated that sustainable economic growth was higher in those transition economies in which reforms were faster than in those with a gradual development strategy (Jakopin, 2012).

With weak growth in the EU, the main export market of the Western Balkans, economic growth in the WBS region requires faster progress in economic reforms. While the economic transformation in the region is mostly completed in the area of monetary stability, the liberalization of prices and trade, a greater effort is needed in building institutions and the infrastructure, improving the business environment and the development of financial markets.

Throughout the observed period (1993-2015), the average growth rate of the real GDP in the EU-15 group was $2 \%$, in the NMS group 3.1\%, and in the WBS group $2.9 \%$. These growth rates enabled an increase in the average GDP per capita (measured by the purchasing power parity), from $\$ 21,328$ to $\$ 45,467$ in the EU-15 group, from $\$ 7,806$ to $\$ 25,942$ in the NMS group, and from $\$ 4,874$ to $\$ 14,441$ in the WBS group (Figure 2).

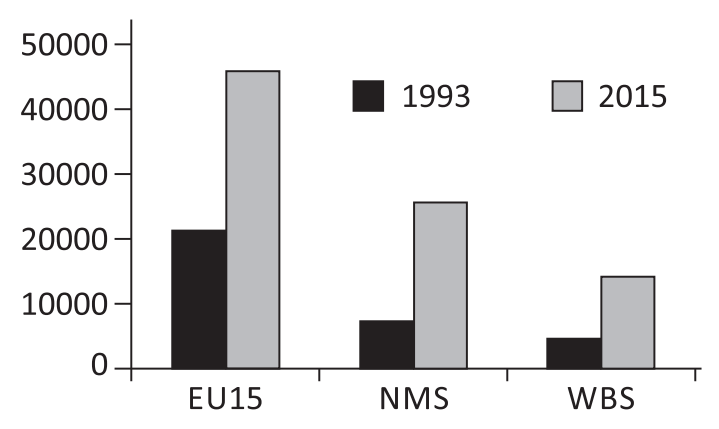

Figure 2 The average GDP per capita (by the purchasing power parity) in the EU-15, the NMS, and the WBS in

1993 and 2015, in current international dollars

Source: Author, based on World Economic Outlook, 2015 
The dynamic of the changes in the GDP per capita (shown in Figure 3) suggests that the growing trend of the GDP per capita was achieved in all the three groups, with an interruption in the midst of the global economic crisis in 2009. After 2010, recovery had the fastest pace in the NMS group, and the slowest in the WBS group.

Although we can draw certain conclusions on the value and trend of the GDP per capita based on these data and the displayed Figures, it still remains unclear whether, in the observed period, income convergence was achieved in the groups of the NMS and the WBS towards the level of income in the EU-15, and whether the two groups differ in terms of the convergence speed. Before moving on to the econometric proving of income convergence, hereinafter follows a theoretical explanation why convergence occurs and on the basis of what it can be expected in the observed countries.

\section{THE THEORETICAL BASIS OF INCOME CONVERGENCE AND THE LITERATURE REVIEW}

Income convergence is usually understood as the process of the difference reduction in the level of income per capita among economies over time. Therefore, convergence occurs if less developed economies grow faster than developed ones. The theoretical explanation for the convergence process and the causes leading to it are provided in the neoclassical model of economic growth (Solow, 1956; Mankiw, Romer \& Weil, 1992). According to that model, the growth of income per capita in the long run is equal to the rate of technological progress. In this case, the economy is in a stable condition. The farther an economy is from its steady state, the faster its growth is. The main reason for a decline in the growth rate with an increase in the level of the achieved income is the decreasing rate of return on capital.

Although, in the long run, all economies grow at the same rate, i.e. at the rate of technological progress, the development level that an economy will reach before reaching a steady state may differ from one state to another. The level of income upon whose reaching an economy grows at the rate of technological progress is determined by the savings rate, the rate of capital depreciation, and the population growth rate. In economies with a higher savings rate, the level of stable income is higher, as opposed to the other two determinants. This means that, in the long term, the levels of the economic development of states with the same characteristics regarding savings rates, the depreciation of capital, and the population growth are equal and that each possible deviation can be attributed to short-term shocks. Achieving the same

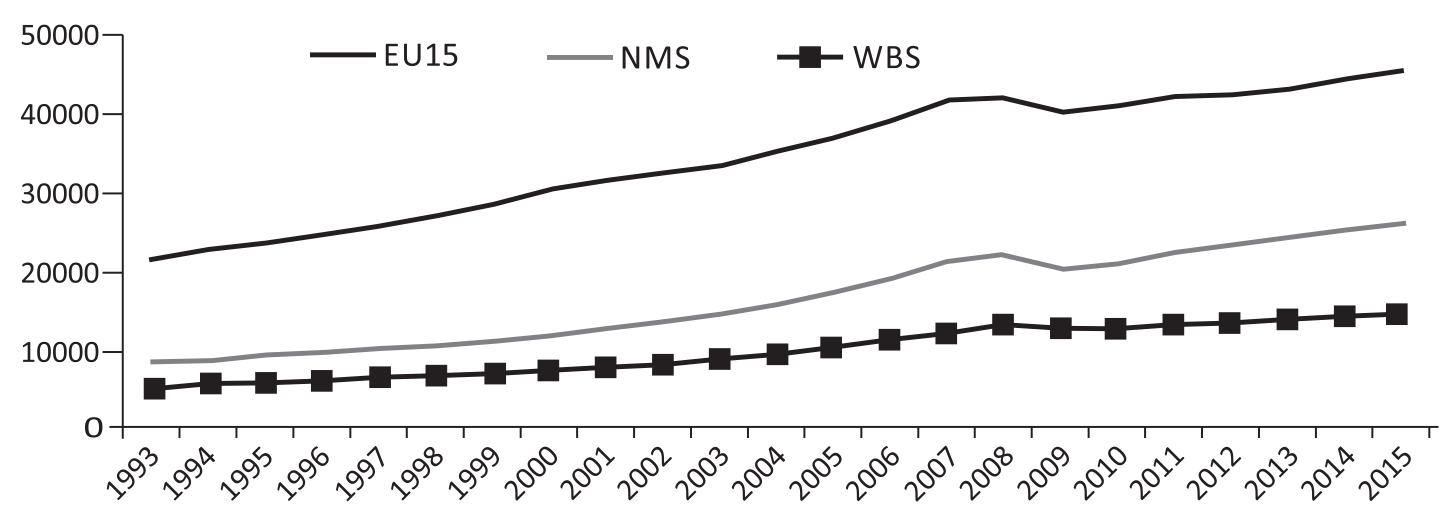

Figure 3 The trends in the average GDP per capita (by the purchasing power parity) in the EU-15, the NMS, and the WBS in the period between 1993 and 2015, in current international dollars 
level of development in a group of states is called absolute convergence.

On the other hand, the states characterized by the different rates of savings, capital depreciation, and the population growth also differ in terms of the stable level of income per capita. However, in this case, the countries farther away from its steady state will grow faster than the countries closer to reaching a steady state in economic development. In other words, in this case, the growth rate of less developed economies is higher than the growth rate of developed economies, although the level of their development will never equalize. This is called conditional convergence.

Although some theories of economic growth disputed the thesis on income convergence later, primarily for abandoning the assumption of diminishing returns on capital, the theories of an international economic integration have given new reasons for its existence. According to them, capital in international frameworks is moving from developed countries to less developed countries, since they have a higher level of the marginal product of capital, i.e. a higher rate of return (the investment risk is abstracted in the model). Furthermore, international trade should lead to the price equalization of the production factors between countries. Both of these characteristics of international economic flows contribute to income convergence between countries.

Empirical studies, on the example of the European Union states, largely confirm the existence of income convergence. The EU enlargement "to the East" in the first decade of this century has contributed to a significant increase in the number of the studies testing the theorem on the convergence of the GDP per capita. In a number of works (Matkowski \& Próchniak, 2004; Kutan \& Yigit, 2004; Kutan \& Yigit, 2005; Varblane \& Vahter, 2005; Próchniak, 2008; Vojinovic \& Oplotnik, 2008; Vojinovic, Acharya \& Próchniak, 2009; Cavenaile \& Dubois, 2011), the authors came to the conclusion that the patterns of the economic growth of the new member states (NMS) in the 1990s and the first decade of the 21st century were in accordance with the income convergence theorem.
Z. Matkowski and M. Próchniak (2004) empirically demonstrated convergence between the transition countries of Central and Eastern Europe (CEE8), as well as between the groups of CEE8 and the EU-15 during the period between 1993 and 2003. The authors conclude that the gap in development between the countries and the groups of the CEE8 and the EU-15, although large, decreases over time. The later studies by these authors, conducted on the same sample of the countries, but over a longer period of time, confirmed the existence of income convergence within the EU, especially among the "old" and the "new" member states (Matkowski \& Próchniak, 2006; Matkowski \& Próchniak, 2007).

Later studies (Próchniak, 2008; Vojinovic \& Oplotnik, 2008; Vojinovic, Acharya \& Próchniak, 2009) also confirm the income convergence of the CEE8 and the EU-15, and the results only differ in the estimated speed of such convergence. L. Cavenaile and D. Dubois (2011) examined the process of income convergence between the ten new member states (NMS) and the EU-15 in the period between 1990 and 2007. The results showed significant differences among the new member states in terms of the speed of their catching up with the average income of the EU developed countries. Large differences in the speed of income convergence are also proven in the work by A. Vamvakidis (2008). An undeniable reduction in the gap at the level of development between the "new" and the "old" member states was confirmed in a study by M. Gligorić (2014). N. Stanisic (2012) confirms the existence of the income convergence of the CEE10 and the EU-15 countries, with an emphasis on the negative impact of the global economic crisis on the convergence speed.

Despite numerous studies on income convergence in the case of the new member states (NMS), the studies on the dynamics of reducing the gap in development between the Western Balkan states (WBS) and the EU15 are rare. E. Tsanana, C. Katrakilidis and P. Pantelidis (2012) analyzed the income convergence of the Balkan Peninsula states and the EU-15 and concluded that it can only be confirmed in the case of Slovenia and Greece, but not in the case of the Western Balkan states (WBS). 
The study of the International Monetary Fund (Murgasova, et al 2015) makes a comparison within the groups of the countries of the NMS and the WBS with respect to the speed of their catching up with the average GDP per capita of the developed EU member states (EU-15). The authors concluded that, in the period between 2000 and 2007, there had been a weak convergence among the countries of the EU-15 and the WBS, primarily because during this period, the underdeveloped economies of the region, such as Bosnia and Herzegovina and Albania, had been growing at a slower pace than the developed countries of the region, such as Croatia. There was a significant income convergence of the NMS and the EU-15 in the same period. For the period after the outbreak of economic crisis, the authors demonstrated the existence of convergence for the WBS group, although weaker, i.e. slower, than the one achieved by the countries of the NMS group.

The scientific contribution of this paper originates from the fact that the number of previous studies on the convergence of the GDP per capita achieved in the Western Balkan states and the EU-15 is very small, as well as that the studies comparing the performance of the Western Balkan states and the NMS are almost non-existent. Moreover, the paper will cover a longer period of time (1993-2015), which includes the economic crisis and the post-crisis recovery, which will make the comparison of the two observed groups (NMS and WBS as well as the picture of the sustainability of the convergence process more complete.

\section{THE RESEARCH METHODOLOGY}

There are two concepts of convergence in the existing econometric models: the sigma $(\sigma)$ and the beta $(\beta)$ convergence. The paper will examine the existence of both types of income convergence. As the measure of income per capita, the GDP per capita was used, adjusted by the purchasing power parity of the currency. The data source is the database of the World Economic Outlook (2015).

The sigma income convergence exists if the difference in the level of income per capita in a certain group of countries reduces over time (Barro \& Sala-and-Martin, 2003). The coefficient of the variation of the real GDP per capita (measured by the purchasing power parity) will be used in this study as the measure of the dispersion of the development level among the observed countries:

$C V(G D P p c)=$ the standard deviation $(G D P p c) /$ the arithmetic
mean $(G D P p c)$

Income convergence exists in a particular group of countries if there is a trend of a reduction in the coefficient of the variation of the GDP per capita over time.

The second form of convergence, the beta convergence, exists if less developed economies grow faster than developed ones, i.e. when there is a negative correlation between the initial level of income per capita and the rates of economic growth in a period of time. In order to prove the beta convergence, the following regression equation was tested on a sample of the Western Balkan states and the new member states:

growth $_{i, t}=\beta_{0}+\beta_{1}$ dist $_{i, t-1}+\beta_{2}$ dist $_{i, t-1} \times W B S+\beta_{3} W B S+u_{i t}$

where growth $_{i, t}$ is the growth rate of the real GDP per capita (measured by the purchasing power parity) of a country in the period $t$; dist $t_{i, t-1}$ the gap in the real GDP per capita between a country and the EU-15 average in the previous period, and the WBS is a dummy variable taking the value of 1 for the countries belonging to the Western Balkans region, and 0 for the countries belonging to the NMS.

The descriptive statistics of the growth and the dist. (distance) variables are presented in Table 1. All of the observed variables have a normal distribution (tested with the Shapiro-Wilk test). Moreover, the assumption of a linear dependence between the

Table 1 Descriptive statistics of variables

\begin{tabular}{l|ccccc}
\hline & $\begin{array}{c}\text { No. of } \\
\text { observations }\end{array}$ & $\begin{array}{c}\text { Arit. } \\
\text { mean }\end{array}$ & $\begin{array}{c}\text { St. } \\
\text { deviation }\end{array}$ & Min. & Max. \\
\hline growth & 352 & 0,557 & 0,487 & $-0,238$ & 0,212 \\
distance & 352 & 0,611 & 0,148 & 0,286 & 0,887 \\
\hline
\end{tabular}

Source: Author 
variables is confirmed, whereas the post-estimation testing determined that there were no problems of multicollinearity (VIF < 10), autocorrelation (DurbinWatson test), and heteroskedasticity (Breusch-Pagan / Cook-Weisberg test).

In addition to examining the existence of convergence, this model also examines whether and to what extent the eventual convergence of the WBS group is different in the speed compared to the convergence of the NMS group, i.e. whether belonging to the WBS group moderates (i.e. changes) the impact the income gap has on the rate of the economic growth of the GDP per capita. Therefore, a new independent variable - the product of dist $t_{i, t-1}$ and the dummy variable WBS - is included in the model.

The positive value of the coefficient $\beta_{1}$ means that there is income convergence in the observed countries (WBS and NMS) and the EU-15, i.e. that the growth rate of real income is higher if the gap in development between the observed country and the EU-15 average is larger. If the coefficient $\beta_{1}$ is higher, convergence is faster.

The statistically significant coefficient $\beta_{2}$ means that belonging to the WBS group moderates the impact that the income gap has on the GDP pc growth rate. The positive value of the coefficient indicates that the speed of convergence in the WBS is higher than the speed of convergence in the NMS. The reverse is true for a negative coefficient $\beta_{2}$.

The coefficient $\beta_{3}$ determines the extent to which the economic growth rates of the WBS group differ from those achieved in the NMS group. The negative value of the coefficient indicates that, at the same income gap with the EU-15 countries, the lower growth rates of the real GDP per capita are achieved in the WBS group than in the NMS group. The reverse is in the case of $\beta_{3}$ coefficient's positive value.

\section{THE RESULTS}

The average level of the GDP per capita in the NMS at the beginning of transition was about $38 \%$, and in Western Balkan states only about 22\% of the level achieved in the EU-15 (Figure 4). Until the beginning of this century, transition had led to no significant increase in income in relation to the EU states. However, since 2000, significant income convergence has been apparent. By 2008, the average GDP per capita had reached $53 \%$ in the group of NMS, whereas it had only reached $30 \%$ of the EU-15 group average in the WBS group.

The outbreak of the global economic crisis in 2008 stopped the process of catching up with the average

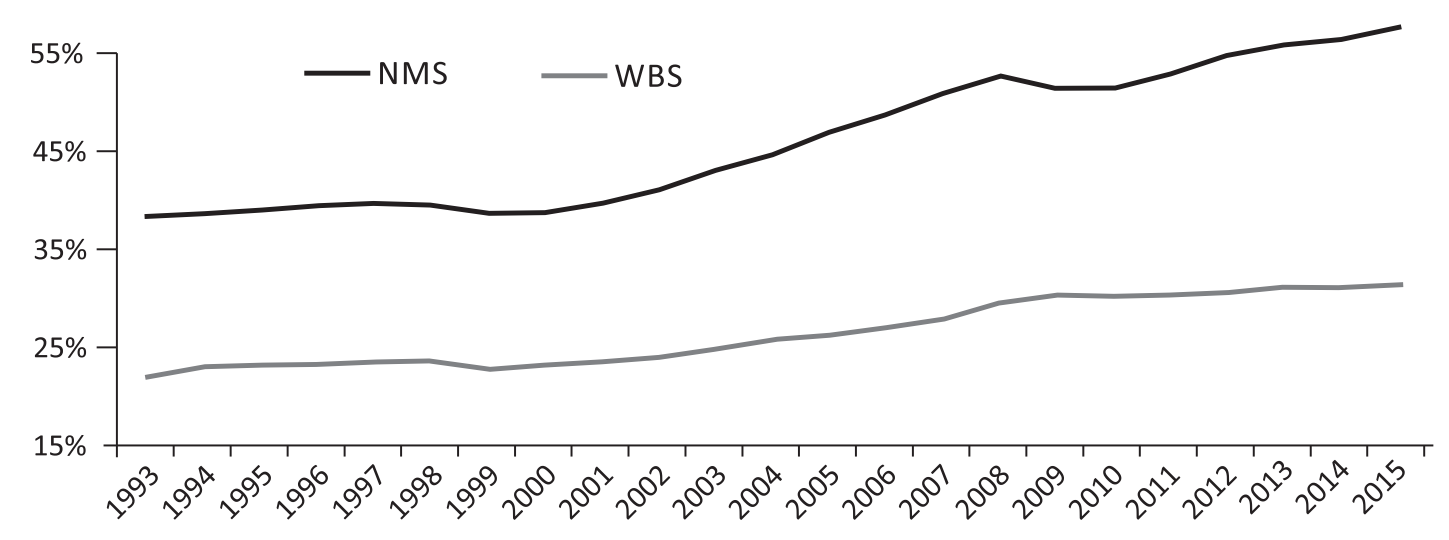

Figure 4 The trends in the GDP per capita (measured by the purchasing power parity) in the NMS and the WBS, in the percentage of the EU-15 
GDP per capita of the EU-15 in countries in transition, in the NMS group only for a short period, and in the WBS group for a longer period of time. Namely, already in 2011, the GDP per capita (compared to the EU-15) in the NMS exceeded the pre-crisis level and continued to grow, reaching $58 \%$ in 2015 . On the other hand, between 2008 and 2015, the GDP per capita compared to the EU-15 increased by only one percentage point (31\% in 2015) in the group of Western Balkan states. After the outbreak of the economic crisis, the income convergence between the WBS and the EU-15 stopped, while the income convergence of the NMS and the EU-15 continued. At the same time, the income gap between the groups of the WBS and the NMS increased.

The results of the convergence of the achieved GDP per capita, using the concept of the sigma income convergence, are shown in Figure 5. The income dispersion (measured by the coefficient of variation) mainly decreased among the countries of the EU-15 + the WBS during the period under review, especially in the period after 2000, until the outbreak of the economic crisis. After 2009, there was a turnaround in the trend, and the dispersion of the achieved GDP per capita was increasing until the end of the observed period. In the group of the NMS + the EU-15, a decrease in the income dispersion during the first decade of this century was even more pronounced, with a brief interruption in 2009 and 2010, after which its further decrease was recorded.

The testing of the $\beta$-convergence with the regression equation (2) was carried out for the entire observed period (Model 4), as well as for the three sub-periods, namely: 1993-2000 (Model 1), 2001-2008 (Model 2) and 2009-2015 (Model 3). The results are accounted for in Table 2. The statistical validity of the model is measured by the coefficient of determination $R^{2}$ (which shows the percentage of the explained variability of the dependent variable), as well as its statistical significance (Prob is the risk of error that the coefficient of determination is not significant; a value below 0.05 indicates the statistically significant coefficient of determination). The results indicate that Model 3 (2009-2015) can be rejected as statistically unreliable.

The value of the coefficient for dist $t_{i, t-1}$ is in all the cases positive, i.e. the greater the gap in development between the countries of the NMS and the WBS groups, on the one hand, and the EU-15 average, on the other, the higher the achieved growth rates of the GDP per capita (PPP). However, the value of this coefficient (which proves the existence of income convergence) is statistically significant $(p<0.05)$ only in the models 2 and 4, i.e. for the entire observed period (1993-2015), and for the subperiod 2001-2008. In the first decade of transition (precisely in the observed subperiod 1993-2000) and after the outbreak of the global economic crisis to date (in the subperiod 2009-2015),

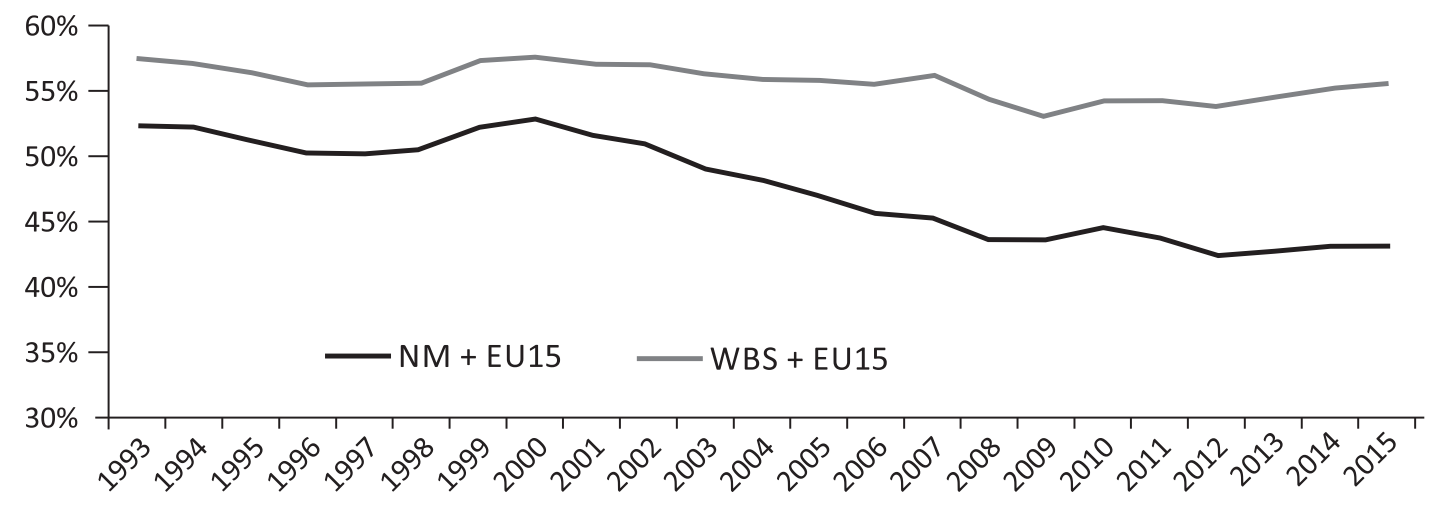

Figure 5 The dispersion of the GDP per capita in the groups of states (measured by the coefficient of variation) 
Table 2 The results of the regression analysis

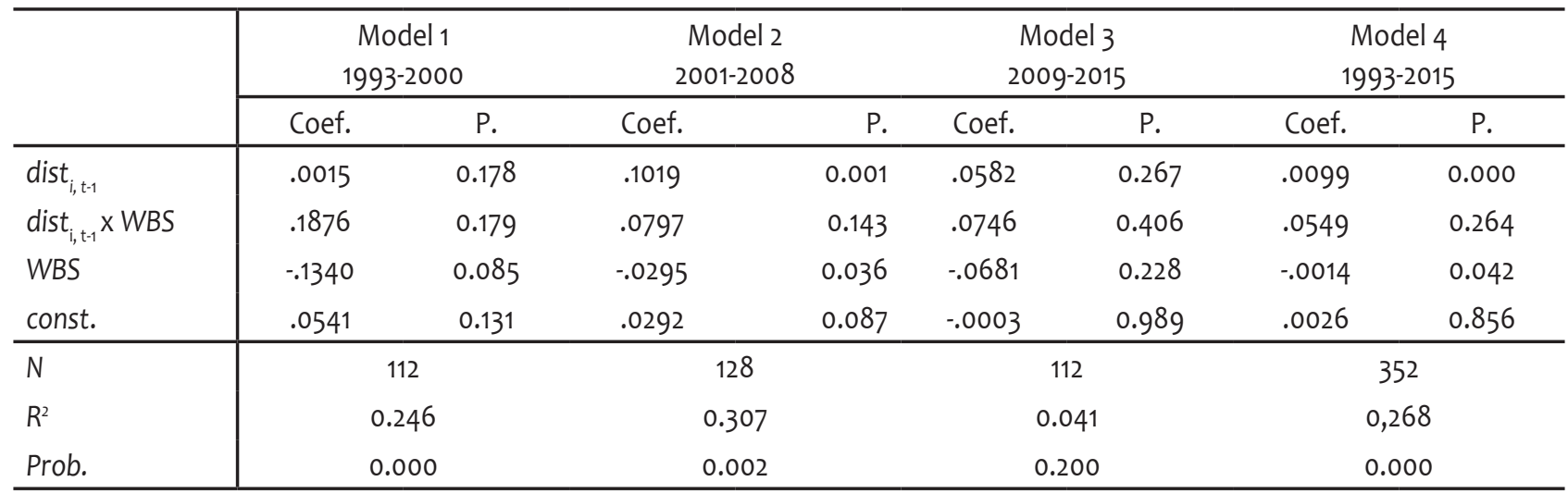

Source: Author

the coefficient is not statistically significant, i.e. the income convergence of the NMS and the WBS, on the one hand, and the EU-15, on the other, has not been proven.

The coefficient for the variable dist $_{i, t-1} \times$ WBS shows the extent to which a country's belonging to the WBS region moderates, i.e. changes the strength of the relationship existing between the income gap and the achieved growth rates of the GDP per capita. The positive value of the coefficient would indicate that the growth of the countries of the WBS group, at the same income gap level, was faster than in the NMS group. However, in all of the tested models, this coefficient is not statistically significant $(p>0.1)$, and we conclude that the relationship between the income gap and the GDP growth per capita was not moderated by a country's belonging to the Western Balkans region. However, this does not mean that the speed of convergence in the NMS and the WBS groups was equal. Before making the final conclusion, it is necessary to look at the value of the coefficient for the dummy variable of the WBS.

The negative value of the coefficient for the variable determining a country's belonging to the WBS region in all the models indicates that, at the same income gap level, the growth rate of the GDP per capita (PPP) was higher for the countries of the NMS group than for the Western Balkan states. In other words, catching up with the average GDP per capita achieved in the EU15 was faster in the case of the NMS than in the case of the WBS. The coefficient is statistically significant in Model $1(p<0.1)$ and Models 2 and $4(p<0.05)$, i.e. in the subperiods 1993-2000, 2001-2008, and the entire observed period 1993-2015.

The results of the regression analysis suggest that income convergence is proven for the NMS and the WBS groups in the period from 1993 to 2015, as well as that it was faster in the case of the NMS.

\section{CONCLUSION}

Catching up with the living standard of the developed economies in Europe was the primary expectation of the citizens of the countries in transition from the transition process and the European integrations of the countries of the former socialist social order in Europe. The neoclassical theories of economic growth and international economic integrations speak in favor of such expectations.

Twenty-five years after the start of the transition, we can conclude that, in terms of the achieved income convergence, the results are different. While the transition countries of Central Europe and the Baltic region significantly increased their GDP per capita (and, in the meantime, became the members of the European Union), the transitional reforms and the results in the Western Balkan states are mostly disappointing. Pointing to the achieved results in catching up with 
the EU-15 income and the comparison of the achieved results of the Western Balkan states (WBS) and the countries in transition which became part of the EU during the first decade of this century, the so-called "new member states" (NMS), was the main objective of the paper.

Although income convergence was a frequent subject of the empirical studies conducted in the case of new member states, there is very small number of the papers on the income convergence per capita achieved in the Western Balkan states and the EU-15, which implies the main contribution of the paper to the existing scientific literature. The scientific contribution of the paper is derived from the fact that the studies comparing the performance of the Western Balkan states and the NMS in terms of catching up with the EU-15 average income are almost non-existent. Moreover, the paper covers a longer time period (19932015) inclusive of the period of the economic crisis and the post-crisis recovery, making the comparison of the two observed groups (the NMS and the WBS) as well as the picture of the convergence process sustainability more complete.

Until the beginning of this century, transition had not led to a reduction in the income gap between the EU and the countries in transition. Only in 2000 was significant catching-up with the EU-15 income achieved in both the NMS and the WBS. The outbreak of the global economic crisis stopped income convergence, which was for a short period in the NMS and for a longer period of time in the WBS. As a result, after the outbreak of the global economic crisis, the income gap between the NMS and the WBS grew.

The testing of the sigma concept of income convergence points to the existence of income convergence in the WBS and the EU-15 after 2000, until the outbreak of the global economic crisis, after which divergence appeared. The convergence of the income per capita in the group of the NMS and the EU-15 had even been faster up to the crisis, only to continue from 2011 after a short interruption. The results confirm the first scientific hypothesis on the convergence of the income per capita achieved in the Western Balkan states and the EU-15 during the period from 2000 to the outbreak of the global economic crisis, after which the reduction in the income gap stopped.

The results of the conducted regression analysis prove the existence of income convergence (the $\beta$ concept) for both groups of countries (the NMS and the WBS), on the one hand, and the EU-15, on the other, in the period between 1993 and 2015, while the convergence speed was higher in the NMS. The same conclusion applies to the period between 2000 and 2008, whereas in the periods 1993-2000 and 2009-2015, the existence of the $\beta$ convergence cannot be confirmed. Thus, the second hypothesis on the equality of the speed of catching up with the average EU-15 GDP per capita between the Western Balkan states and the new member states can be dismissed.

The economic crisis removed the mask from the solid economic growth of the pre-crisis period in the Western Balkans and revealed all the shortcomings of the existing economic system of the (un)implemented reforms and models of economic growth, based mainly on the growth of domestic demand. It was only after the outbreak of the crisis that it became apparent that transition in the Western Balkans region differed in the results from the one in the NMS.

The conducted research raises many questions for further research, primarily what the key factors to have led to the significantly different results of transition in the groups of the NMS and the WBS are. Furthermore, an economy's success should be assessed according to what happens to the standard of the living of the majority of the citizens over a longer period, rather than according to the achieved average GDP per capita. In this sense, no economy can be said to function well, even though it has achieved an increase in the GDP per capita, if there is growth in inequality in income distribution within a country (Lekovic, 2015). In this sense, the results of income convergence could be supplemented by reviewing the degree of internal income inequalities during the transition period.

\section{REFERENCES}

Barro, R. J., \& Sala-i-Martin, X. (2003). Economic Growth. Cambridge: MIT Press. 
Cavenaile, L., \& Dubois, D. (2011). An empirical analysis of incomeconvergencein the EuropeanUnion. Applied Economics Letters, 18(17), 1705-1708. doi: 10.1080/13504851.2011.560104

Gligorić, M. (2014). Paths of income convergence between country pairs within Europe. Economic Annals, 59(201), 123156. doi:10.2298/eka1401123g

Jakopin, E. (2012). Post-crisis reallocation of growth factors. Economic Horizons, 14(2), 79-90. doi:10.5937/ekonhor1202077J

Kutan, A. M., \& Yigit, T. M. (2004). Nominal and real stochastic convergence of transition economies. Journal of Comparative Economics, 32(1), 23-36. doi: 10.1016/j.jce.2003.09.008

Kutan, A. M., \& Yigit, T. M. (2005). Real and nominal stochastic convergence: Are the new EU members ready to join the Euro zone? Journal of Comparative Economics, 33(2), 387-400. doi:10.1016/j.jce.2005.03.001

Lekovic, V. (2015). Determinants of economic (in)equality and its implications for sustainable economic development. Economic Horizons, 17(2), 79-94. doi: 10.5937/ekonhor1502081L

Mankiw, N. G., Romer, D., \& Weil, D. N. (1992). A contribution to the empirics of economic growth. The Quarterly Journal of Economics, 107(2), 407-437. doi: 10.2307/2118477

Matkowski, Z., \& Prochniak, M. (2004). Real economic convergence in the EU accession countries. International Journal of Applied Econometrics and Quantitative Studies, 1(3), 5-38.

Matkowski, Z., \& Prochniak, M. (2006). Convergence of the economic growth of accession countries in relation to the European Union. In D. Rosati (Ed.). New Europe. Report on Transformation (pp. 169-180). Warsaw: Institute for Eastern Studies.

Matkowski, Z., \& Prochniak, M. (2007). Economic convergence between the CEE-8 and the European Union. Eastern European Economics, 45(1), 59-76. doi: 10.2753/EEE00128775450103

Murgasova, Z., Ilahi, N., Miniane, J., Scott, A., \& VladkovaHollar, I. (2015). The Western Balkans: 15 years of economic transition. Washington DC: International Monetary Fund.
Prascevic, A. (2013). Achievements of economic policy in overcoming the effects of the global economic crisis on Serbian Economy. Economic Horizons, 15(1), 19-32. doi:10.5937/ ekonhor1301017P

Prochniak, M. (2008). Real economic convergence between Central and Eastern Europe and the European Union. Paper presented at the conference China's Three Decades of Economic Reforms, Chinese Economic association and Cambridge University.

Solow, R. (1956). A contribution to the theory of economic growth. Quarterly Journal of Economics, 70(1), 65-94. doi: $10.2307 / 1884513$

Stanisic, N. (2012). The effects of the economic crisis on income convergence in the European Union. Acta Oeconomica, 62(2), 161-182, doi: 10.1556/AOecon.62.2012.2.2

Tsanana, E., Katrakilidis, C., \& Pantelidis, P. (2012). Balkan area and EU-15: An empirical investigation of income convergence. In A. Karasavvoglou, \& P. Polychronidou (Eds.). Balkan and Eastern European Countries in the Midst of the Global Economic Crisis, Contributions to Economics, Berlin Heidelberg: Springer-Verlag, doi: 10.1007/978-3-7908-2873$3 \_2$

Vamvakidis, A. (2008). Convergence in emerging Europe: Sustainability and Vulnerabilities. IMF Working Paper WP/08/181, Washington DC: International Monetary Fund

Varblane U., \& Vahter, P. (2005). An analysis of the Economic Convergence process in the Transition Countries. University of Tartu-Faculty of Economics \& Business Administration Working Paper Series, 37

Vojinovic, B., \& Oplotnik, Z. (2008). Real convergence in the new EU member states. Praque Economic Papers, 17(1), 23-39. doi: $10.18267 /$ j.pep.317

Vojinovic, B., Acharya, S., \& Prochniak, M. (2009). Convergence analysis among the ten European transition economies. Hitotsubashi Journal of Economics, 50(2), 123-141.

World Economic Outlook. (2015). Washington DC: International Monetary Fond

Received on $8^{\text {th }}$ March 2016, after revision, accepted for publication on $14^{\text {th }}$ April 2016. Published online on $25^{\text {th }}$ April 2016. 
Nenad Stanisic is an Associate Professor at the Faculty of Economics, University of Kragujevac, Kragujevac, the Republic of Serbia. He received a PhD degree in international economics at the Faculty of Economics, University of Belgrade. The key areas of his scientific interest are international economic relations, international trade and finance and international economic integrations. 


\title{
DOHODOVNA KONVERGENCIJA U PROCESU PRIDRUŽIVANJA ZEMALJA ZAPADNOG BALKANA EVROPSKOJ UNIJI
}

\author{
Nenad Stanišić* \\ Ekonomski fakultet Univerziteta u Kragujevcu
}

Porast životnog standarda, uz sustizanje nivoa dohotka po stanovniku koji se ostvaruje u razvijenim evropskim ekonomijama, jedno je od osnovnih očekivanja stanovništva evropskih tranzicionih ekonomija. Četvrt veka nakon otpočinjanja tranzicije, mnoge tranzicione zemlje su ušle u Evropsku uniju (EU) i značajno povećale bruto domaći proizvod po stanovniku. $S$ druge strane, tranzicija u zemljama tzv. Zapadnog Balkana je, u tom smislu, razočarala. U radu se testira postojanje i brzina konvergencije dohodaka zemalja Zapadnog Balkana i razvijenih zemalja EU, uz poređenje sa tzv. „novim članicama EU“. Rezultati ukazuju da je, uprkos ostvarenoj konvergenciji dohodaka u pretkriznim godinama, izbijanje Globalne ekonomske krize razotkrilo mnoge strukturne i reformske probleme sa kojima se zemlje regiona susreću u dužem vremenskom razdoblju. Smanjivanje razlika u ekonomskoj razvijenosti između razvijenih članica EU i zemalja Zapadnog Balkana zaustavljeno je nakon početka Globalne krize, uz istovremeni rast dohodovnog jaza između zemalja Zapadnog Balkana i novih članica EU.

Ključne reči: konvergencija dohodaka, ekonomski razvoj, ekonomije Zapadnog Balkana, evropske ekonomske integracije

\section{JEL Classification: 047, P27, F43}

\section{UVOD}

Iako je ekonomska tranzicija ka kapitalizmu i tržišnoj privredi praćena brojnim problemima $u$ svim evropskim tranzicionim ekonomijama, ona se posebno teško i sporo odvija u regionu Zapadnog Balkana (Hrvatska, Bosna i Hercegovina, Crna Gora, Srbija, Makedonija i Albanija). Mnoge zemlje

\footnotetext{
* Korespondencija: N. Stanišić, Ekonomski fakultet Univerziteta u Kragujevcu, Đ. Pucara 3, 34000 Kragujevac, Republika Srbija; e-mail: nstanisic@kg.ac.rs
}

Zapadnog Balkana su znatan deo 1990-ih godina provele u razarajućim konfliktima, međunacionalne ili unutrašnje prirode, što je odložilo početak značajnijih tranzicionih reformi. Nakon „izgubljene decenije“, zemlje regiona su XXI vek započele u politički stabilnijem okruženju, okrenute ka ekonomskom razvoju i sa ciljem povećanja životnog standarda, koji je tokom poslednje decenije XX-og veka pretrpeo značajan pad. Ono što je, takođe, postalo zajedničko svim zemljama ovog regiona je strateška opredeljenost za članstvo u Evropskoj uniji (EU), usled čega 
je ekonomska tranzicija na Zapadnom Balkanu neodvojiva od procesa evropskih integracija, baš kao što je to bio slučaj i u ostalim tranzicionim evropskim zemljama.

$\mathrm{U}$ proteklih petnaest godina, $\mathrm{u}$ zemljama Zapadnog Balkana postignut je značajan ekonomski napredak (Murgasova, Ilahi, Miniane, Scott \& VladkovaHollar, 2015). Sve zemlje su započele transformaciju ka tržišnim ekonomijama, privatizovale veliki deo neefikasnih društvenih i državnih preduzeća, reformisale bankarski sistem, otvorile svoje privrede ka evropskom i ostalim svetskim tržištima, započele značajna infrastrukturna ulaganja i reformu institucija i propisa. Kao rezultat toga, došlo je do povećanja bruto domaćeg proizvoda (BDP), BDP per capita i konvergencije dohodaka zemalja ovog regiona i razvijenih zemalja EU. Ipak, brzina sprovođenja reformi nije bila dovoljna, te se čitav region, i posle petnaest godina, nalazi u stanju nedovršene tranzicije. Mnogi reformski zadaci nisu izvršeni na zadovoljavajući način. Privatizacija, izgradnja institucija, pravnog sistema nisu dali očekivane rezultate. Svi ti ekonomski neuspesi se ogledaju u jednom pokazatelju - i dalje niskom nivou životnog standarda, tj. dohotka po stanovniku.

Predmet istraživanja u ovom radu je konvergencija dohotka zemalja Zapadnog Balkana i razvijenih zemalja EU, tj. sagledavanje tendencija u smanjivanju jaza koji postoji u ekonomskoj razvijenosti ove dve grupe zemalja.

Osnovni cilj istraživanja je da se analizom dinamike i trendova u promeni BDP per capita ustanovi da li se zemlje regiona nalaze na putu sustizanja nivoa životnog standarda EU. U ocenjivanju uspešnosti tranzicije na Zapadnom Balkanu u obzir će biti uzeto i iskustvo tranzicionih zemalja koje su proces evropskih integracija okončale ulaskom $u$ EU tokom prve decenije XXI veka, tzv. „novih zemalja članica“" (New Member States - NMS). Zato je dodatni cilj istraživanja identifikovanje razlika (ukoliko one postoje) u pogledu brzine konvergencije dohotka razvijenih članica EU, s jedne strane, i NMS, odnosno, zemalja Zapadnog Balkana (Western Balkan States - WBS), s druge strane.

U skladu sa navedenim predmetom i ciljem istraživanja definisane su sledeće istraživačke hipoteze:
H1: Nivo dohotka u zemljama Zapadnog Balkana se približava nivou dohotka u razvijenim članicama EU.

H2: Brzina sustizanja prosečnog BDP per capita razvijenih članica EU je jednaka u zemljama Zapadnog Balkana i „novim članicama“ EU.

Dohodovna konvergencija može biti dokazana na dva načina. Po prvom, konvergencija postoji ukoliko se tokom vremena smanjuje disperzija dohotka među zemljama unutar posmatrane grupe (tzv. $\sigma$ konvergencija). Po drugom pristupu, konvergencija postoji ukoliko ekonomije koje se inicijalno nalaze na nižem stepenu razvoja rastu brže od onih koje su razvijenije (tzv. $\beta$ konvergencija). Konvergencija dohodaka zemalja Zapadnog Balkana i razvijenih članica EU će u ovom radu biti testirana primenom oba navedena koncepta.

Rad se sastoji od šest sekcija. Posle Uvoda, sagledane su osnovne karakteristike ekonomskog rasta i porasta životnog standarda u regionu Zapadnog Balkana. U trećoj sekciji su predstavljeni teorijski osnovi dohodovne konvergencije i rezultati relevantnih empirijskih istraživanja. U četvrtoj sekciji se objašnjava metodologija istraživanja, dok su rezultati istraživanja prezentovani u petoj sekciji rada. Šesta sekcija sumira zaključke i definiše moguće pravce daljih istraživanja.

\section{EKONOMSKI RAST I RAST ŽIVOTNOG STANDARDA U ZEMLJAMA ZAPADNOG BALKANA}

Početak poslednje decenije XX-og veka je u većini današnjih država regiona Zapadnog Balkana obeležio ekonomski kolaps, oštar pad ekonomske aktivnosti i životnog standarda, a sve to kao posledica konflikata i stvaranja novih država na teritoriji bivše SFRJ. Kasniji oporavak je imao nejednak tempo u novostvorenim državama, uz izraženu promenljivost stopa ekonomskog rasta. Do kraja XX-og veka, BDP per capita je dostigao nivo iz 1990. godine. Iako bez sukoba i konflikata, početak tranzicije je i u regionu Centralne Evrope započeo recesijom.

Na Slici 1 su prikazane prosečne godišnje stope rasta realnog BDP u periodu od 1993. do 2015. godine, u 
tri potperioda (1993-2000, 2001-2008, 2009-2015), za tri grupe zemalja:

- razvijene ekonomije EU, EU15: Nemačka, Francuska, Italija, Belgija, Holandija, Luksemburg, Velika Britanija, Danska, Irska, Grčka, Portugal, Španija, Austrija, Švedska i Finska;

- „nove članice“ EU (NMS): Poljska, Češka, Slovačka, Mađarska, Slovenija, Litvanija, Letonija, Estonija, Rumunija i Bugarska; i

- zemlje Zapadnog Balkana (WBS): Hrvatska, Bosna i Hercegovina, Crna Gora, Republika Srbija, BJR Makedonija i Albanija.

Imajući $u$ vidu navedene teškoće $u$ početnoj fazi tranzicije $u$ skoro svim zemljama, ne čudi da je $u$ poslednjoj deceniji XX-og veka najveći ekonomski rast ostvaren u zemljama Evropske unije. Prosečna godišnja stopa rasta realnog BDP je u periodu 19932000. godine je bila najviša u grupi EU15 (3,8\%), dok je u grupi zemalja NMS iznosila 2,9\%, a u grupi WBS 3,0\% (Slika 1).

XXI vek je tranzicionim zemljama doneo novi zamah $\mathrm{u}$ ekonomskom rastu. Zemlje Centralne Evrope i Baltičke regije su se uveliko bližile momentu ulaska $\mathrm{u}$ EU, a balkanske zemlje su, jasno opredeljene za isti put, započele značajnije reforme. Zajedno posmatrano, region Zapadnog Balkana je u periodu 2001-2008. godine ostvario značajne rezultate $u$ porastu dohotka i životnog standarda, mada ne baš onakve kakvi su očekivani. Sa prosečnom stopom godišnjeg rasta realnog BDP od 5,2\%, zemlje Zapadnog Balkana su smanjivale razliku u razvijenosti koja je postojala između nih i EU15 (prosečna godišnja stopa rasta realnog BDP je $\mathrm{u}$ istom periodu u EU15 iznosila 2,3\%). Ipak, ostvarena konvergencija nije bila u potpunosti zadovoljavajuća, jer je $\mathrm{u}$ istom periodu u grupi NMS ostvarena veća prosečna stopa rasta realnog BDP od $5,7 \%$. Pri višem nivou BDP per capita u odnosu na WBS, navedena stopa rasta je grupi NMS omogućila brže sustizanje dohotka EU15. Tada je već postalo jasno da tranzicija $u$ regionu Zapadnog Balkana ne daje iste rezultate kao u ostalim regionima Evrope.

Proces strukturne transformacije privreda Zapadnog Balkanaje usporen sredinom prve decenije XXI-og veka, a loša reformska rešenja i još lošiji rezultati u pojedinim segmentima tranzicije su usporili dalji ekonomski napredak. Moglo bi se tvrditi da je ekonomski rast od tada do izbijanja Globalne ekonomske krize krajem 2008. godine $\mathrm{u}$ regionu Zapadnog Balkana pre bio rezultat tendencija u globalnoj privredi, rastuće likvidnosti na svetskom tržištu kapitala, značajnom prilivu stranog kapitala i kreditnom bumu, nego stvarnog napretka u ekonomskim reformama (Murgasova et al, 2015). Jasan dokaz lošeg ekonomskog modela u zemljama Zapadnog Balkana je ekstremno visoka stopa nezaposlenosti, preko 20\%, tj. nepotpuna

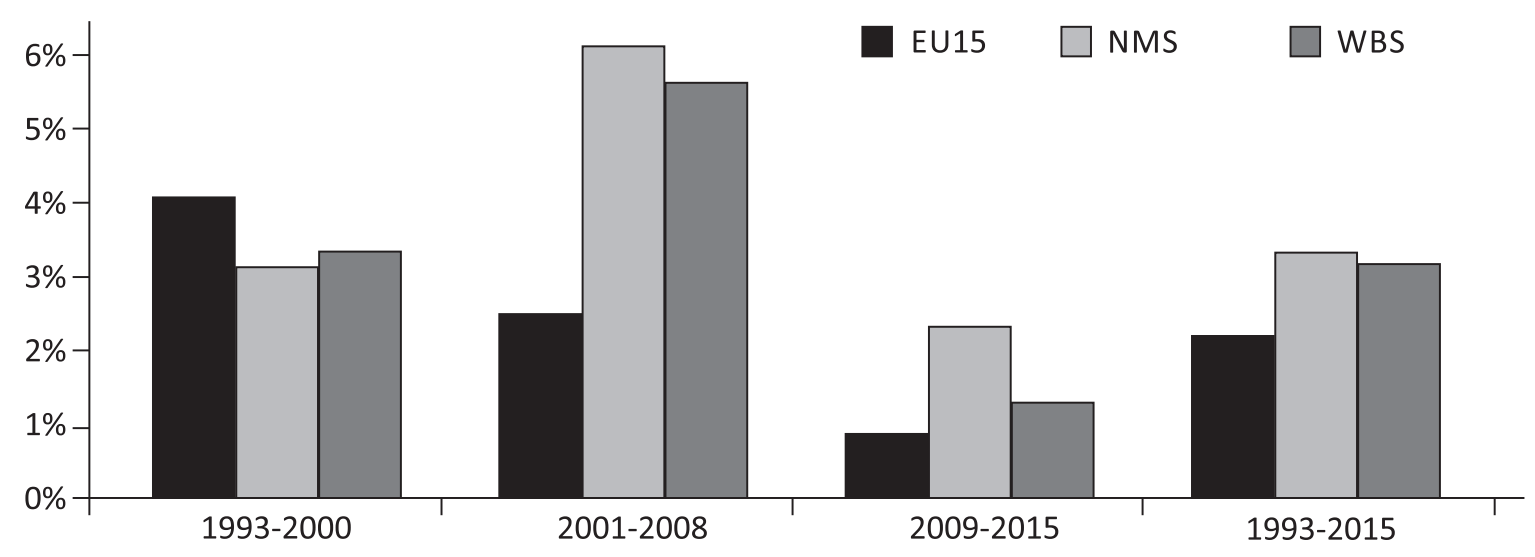

Slika 1 Prosečne stope rasta realnog BDP per capita u EU15, NMS i WBS 
upotreba raspoloživih ljudskih resursa, čak i u periodu solidnog ekonomskog rasta $u$ pretkriznom periodu. Razlika u tempu i načinu sprovođenja reformi među zemljama NMS i WBS je osnovni uzrok razlike u brzini dohodovne konvergencije ove dve grupe zemalja prema nivou razvijenih zemalja EU.

Godine ekonomskog rasta prekinute su 2009. izbijanjem Globalne ekonomske krize. Skoro sve evropske zemlje su zabeležile pad ekonomija. Ni postkrizni oporavak nije bio brz. Ni 2015, šest godina nakon izbijanja Krize, evropske ekonomije nisu u uzletu. Među zemljama EU, Krizu je najbrže prebrodio region Centralne Evrope. Prosečna godišnja stopa rasta realnog BDP je u grupi NMS iznosila 2,2\% u periodu 2009-2015. U istom periodu, stopa rasta je u EU15 iznosila 0,8\%, a u grupi WBS $1,2 \%$. Ostvarene stope rasta donele su regionu NMS nov zamah u sustizanju prosečnog dohotka zemalja EU15, a regionu WBS skoro pa stagnaciju.

Godine ekonomske krize zbacile su masku sa solidnog ekonomskog rasta iz pretkriznog perioda u regionu Zapadnog Balkana i otkrile sve nedostatke postojećeg ekonomskog uređenja, pre svega izbor modela privrednog rasta baziranog na agregatnoj tražnji (i to domaćoj tražnji) i političku nastabilnost i vođenje ekonomske politike u uslovima koalicionih vlada (Prascevic, 2013). Globalna recesija je potvrdila da privredni rast nije moguć bez kontinuiranih strukturnih promena. Istraživanja su ukazala da je održiv privredni rast bio veći $u$ onim tranzicionim ekonomijama u kojima su reforme bile brže od onih sa strategijom postepenog razvoja (Jakopin, 2012).

Uz slab rast u EU, glavnom izvoznom tržištu zemalja Zapadnog Balkana, ekonomski rast u regionu WBS zahteva brži napredak u ekonomskim reformama. Dok je ekonomska transformacija $u$ regionu uglavnom završena $\mathrm{u}$ domenu monetarne stabilnosti, liberalizacije cena i trgovine, više napora je potrebno $\mathrm{u}$ izgradnji institucija i infrastrukture, unapređenju poslovnog okruženja i razvoju finansijskih tržišta.

U toku celog posmatranog perioda (1993-2015), prosečna stopa rasta realnog BDP u grupi EU15 je iznosila $2 \%$, u grupi NMS 3,1\%, a u grupi WBS 2,9\%. Navedene stope rasta su omogućile porast prosečnog BDP per capita (merenog paritetom kupovnih moći) sa 21.328 na 45.467 USD u grupi EU15, sa 7.806 na 25.942
USD u grupi NMS, i sa 4.874 na 14.441 USD u grupi WBS (Slika 2).

Dinamika promene BDP per capita (Slika 3) upućuje na zaključak da je u sve tri grupe zemalja ostvaren rastući trend kretanja BDP per capita, sa prekidom u jeku Globalne ekonomske krize 2009. Oporavak je, nakon 2010, imao najbrži tempo u grupi NMS, a najslabiji u grupi WBS.

Iako se na osnovu navedenih podataka, predstavljenih slikama 1, 2 i 3, mogu izvući zaključci o visini i kretanju BDP per capita, ostaje nejasno da li je u posmatranom periodu došlo do dohodovne konvergencije u grupama NMS i WBS ka nivou dohotka u EU15, i da li se odnosne dve grupe razlikuju po brzini konvergencije. Ekonometrijsko dokazivanje konvergencije dohodaka podrazumeva prethodno teorijsko objašnjenje zbog čega do konvergencije dolazi i na osnovu čega se ona može očekivati u posmatranim zemljama.

\section{TEORIJSKA OSNOVA DOHODOVNE KONVERGENCIJE I PREGLED LITERATURE}

Konvergencija dohodaka se najčešće shvata kao proces smanjivanja razlika $u$ nivou dohotka po stanovniku među ekonomijama tokom vremena. Do

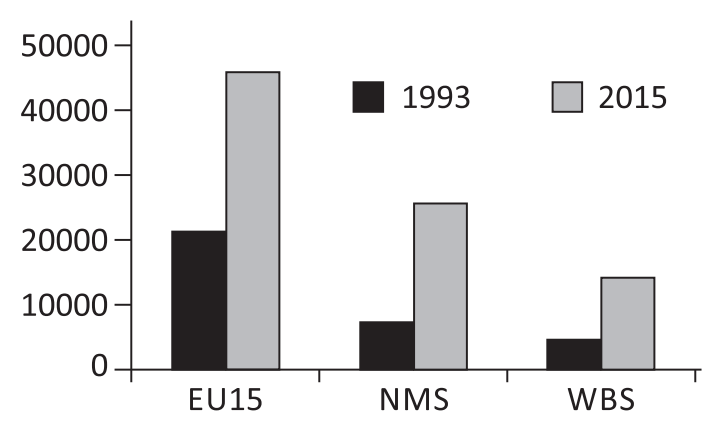

Slika 2 Prosečan BDP per capita (po paritetu kupovnih moći) u EU15, NMS i WBS u 1993 i 2015. godini, u tekućim međunarodnim dolarima

Izvor: Autor, na osnovu World Economic Outlook, 2015 


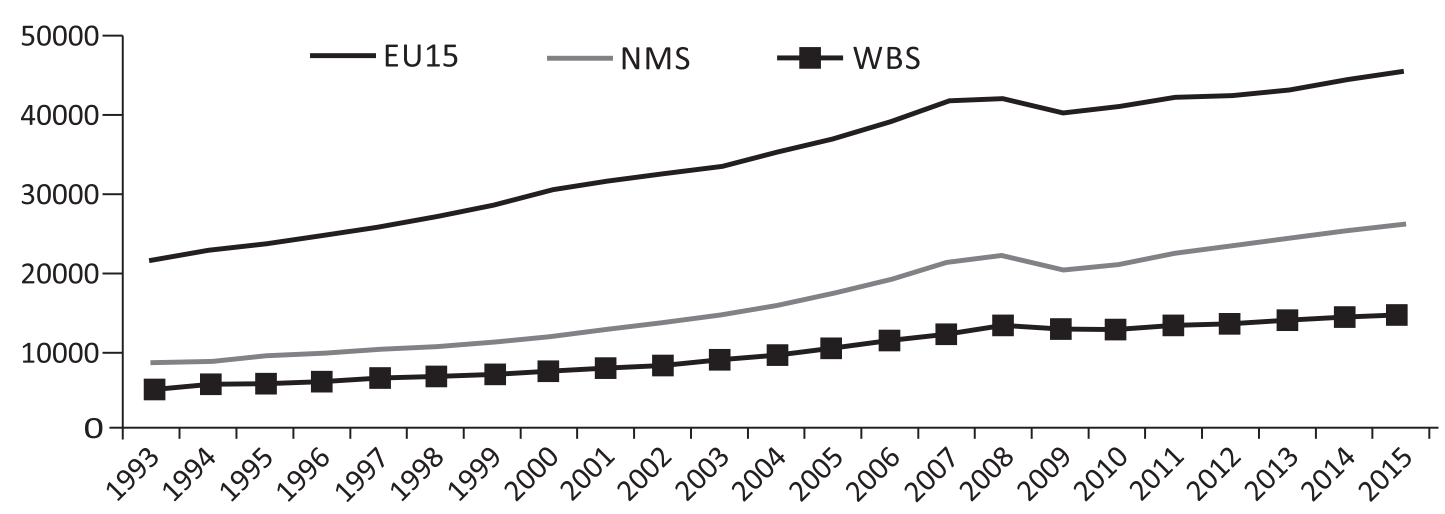

Slika 3 Kretanje prosečnog BDP per capita (po paritetu kupovnih moći) u EU15, NMS i WBS u periodu 1993-2015, u tekućim međunarodnim dolarima

Izvor: Autor

konvergencije, dakle, dolazi ukoliko manje razvijene ekonomije rastu brže od razvijenih. Teorijsko objašnjenje procesa konergencije i uzroka koji do nje dovode dato je u neoklasičnom modelu ekonomskog rasta (Solow, 1956; Mankiw, Romer \& Weil, 1992). Prema dotičnom modelu, rast dohotka po stanovniku je u dugom roku jednak stopi tehnološkog progresa. U tom slučaju, ekonomija se nalazi u stabilnom stanju. Što se ekonomija nalazi dalje od svog stabilnog stanja, rast je brži. Osnovni razlog za opadanje stope rasta sa porastom nivoa dostignutog dohotka je opadajuća stopa prinosa na kapital.

Iako $\mathrm{u}$ dugom roku sve ekonomije rastu jednakom stopom, tj. stopom tehnološkog progresa, nivo razvijenosti koji će ekonomija dostići pre nego što postigne stabilno stanje se može razlikovati među zemljama. Nivo dohotka nakon čijeg dostizanja ekonomija raste po stopi tehnološkog progresa je determinisan stopom štednje, stopom depresijacije kapitala i stopom rasta populacije. Za ekonomije sa višom stopom štednje, nivo stabilnog dohotka je viši, dok obrnuto važi za ostale dve determinante. Ovo znači da su, dugoročno posmatrano, nivoi ekonomske razvijenosti zemalja sa istim karakteristikama $u$ pogledu stope štednje, depresijacije kapitala i rasta stanovništva jednaki, a da se svako eventualno odstupanje može pripisati kratkoročnim šokovima.
Dostizanje jednakog nivoa razvijenosti u grupi zemalja se naziva apsolutna konvergencija.

S druge strane, zemlje koje karakterišu različite stope štednje, depresijacije kapitala i porasta stanovništva razlikuju se i u pogledu stabilnog nivoa dohotka po stanovniku. Ipak, i u tom slučaju će zemlje koje su udaljenije od svog stabilnog stanja rasti brže od zemalja koje su bliže dostizanju stabilnog stanja u ekonomskom razvoju. Drugim rečima, i u ovom slučaju je stopa rasta manje razvijenih ekonomija viša od stope rasta razvijenijih ekonomija, iako se nivo razvijenosti nikad neće izjednačiti. Ovo se naziva uslovna konvergencija.

Iako su neke kasnije teorije ekonomskog rasta osporile tezu o konvergenciji dohodaka, pre svega, zbog napuštanja pretpostavke opadajućih prinosa na kapital, teorije međunarodne ekonomske integracije su dale nove razloge za njeno postojanje. Prema njima, kapital se u međunarodnim okvirima kreće iz razvijenih zemalja ka manje razvijenim zemljama, jer je u njima viši nivo marginalnog proizvoda kapitala, tj. viša stopa prinosa (rizik ulagnja je u modelu apstrahovan). Takođe, međunarodna trgovina bi trebalo da dovede do izjedančavanja cena faktora proizvodnje među zemljama. Obe navedene karakteristike međunarodnih ekonomskih tokova doprinose konvergenciji dohodaka među zemljama. 
Empririjske studije na primeru zemalja Evropske unije, uglavnom, potvrđuju postojanje konvergencije dohodaka. Proširivanje EU „na istok“ u prvoj deceniji XXI-og veka doprinelo je značajnom porastu broja studija u kojima se testira Teorema o konvergenciji BDP per capita. U brojnim radovima (Matkowski \& Prochniak, 2004; Kutan \& Yigit, 2004; Kutan \& Yigit, 2005; Varblane \& Vahter, 2005; Prochniak, 2008; Vojinovic \& Oplotnik, 2008; Vojinovic, Acharya \& Prochniak, 2009; Cavenaile \& Dubois, 2011), autori su došli do zaključka da je ostvareni ekonomski rast novih članica EU (NMS) tokom 1990-ih godina i u prvoj deceniji XXI-og veka bio u skladu sa Teoremom o dohodovnoj konvergenciji.

Z. Matkowski i M. Prochniak (2004) su empirijski dokazali konvergenciju među tranzicionim zemljama Centralne i Istočne Evrope (CEE8), i među grupama CEE8 i EU15, u periodu 1993-2003. Autori zaključuju da se jaz u nivou razvijenosti između zemalja grupe CEE8 i EU15, iako veliki, vremenom smanjuje. Kasnije studije ovih autora, rađene na istom uzorku zemalja, ali u dužem vremenskom razdoblju, potvrdile su postojanje dohodovne konvergencije unutar EU, posebno među "starim" i „novim“ članicama (Matkowski \& Prochniak, 2006; Matkowski \& Prochniak, 2007).

I kasnije studije (Prochniak, 2008; Vojinovic \& Oplotnik, 2008; Vojinovic, Acharya \& Prochniak, 2009) potvrđuju konvergenciju dohodaka CEE8 i EU15, a rezulteti se razlikuju samo u procenjenoj brzini konvergencije. L. Cavenaile i D. Dubois (2011) su ispitivali proces dohodovne konvergencije između deset novih članica EU (NMS) i EU15 u periodu 19902007. Rezultati su ukazali na postojanje značajnih razlika među novim članicama EU u pogledu brzine sustizanja prosečnog dohotka razvijenih zemalja EU. Velike razlike $u$ brzini dohodovne konvergencije su dokazane i u radu A. Vamvakidis-a (2008). Neosporno smanjivanje jaza u nivou razvijenosti između "novih“ i „starih“ zemalja članica EU potvrđeno je i u studiji M. Gligorić (2014). N. Stanisic (2012) potvrđuje postojanje konvergencije dohodaka zemalja CEE10 i EU15, uz isticanje negativnog uticaja Globalne ekonomske krize na brzinu konvergencije.

Uprkos brojnim studijama o dohodovnoj konvergenciji na primeru novih članica EU (NMS), istraživanja o dinamici smanjivanja jaza $u$ razvijenosti između zemalja Zapadnog Balkana (WBS) i EU15 su retka. E. Tsanana, C. Katrakilidis i P. Pantelidis (2012) su analizirali konvergenciju dohodaka zemalja Balkanskog poluostrva i EU15 i zaključili da se ona može potvrditi samo u slučaju Slovenije i Grčke, a ne i u slučaju zemalja Zapadnog Balkana (WBS).

U studiji Međunarodnog monetarnog fonda (Murgasova, et al, 2015) poređene su grupe zemalja NMS i WBS u brzini sustizanja prosečnog BDP per capita razvijenih članica EU (EU15). Autori zaključuju da je u periodu 2000-2007. ostvarena slaba konvergencija među zemljama WBS i EU15, pre svega, iz razloga što su u tom periodu slabije razvijene ekonomije regiona, kao što su Bosna i Hercegovina i Albanija, rasle sporije od razvijenijih zemalja regiona, kao što je Hrvatska. $\mathrm{U}$ istom periodu, došlo je do značajne konvergencije dohodaka NMS i EU15. Za period nakon izbijanja ekonomske krize, autori su dokazali postojanje konvergencije za grupu WBS, iako slabiju, tj. sporiju od one koju ostvaruju zemlje grupe NMS.

Naučni doprinos ovog rada proizilazi iz činjenice da je broj ranijih studija o konvergenciji BDP per capita ostvarenog u zemljama Zapadnog Balkana i EU15 mali, kao i da istraživanja koja upoređuju performanse zemalja Zapadnog Balkana i NMS skoro i ne postoje. Takođe, radom će biti obuhvaćen duži vremenski period (1993-2015), koji uključuje i godine Globalne ekonomske krize i postkriznog oporavka, čime će komparacija dveju posmatranih grupa (NMS i WBS), kao i slika o održivosti procesa konvergencije, biti potpunija.

\section{METODOLOGIJA ISTRAŽIVANJA}

Postojeći ekonometrijski modeli razlikuju dva koncepta konvergencije: sigma $(\sigma)$ i beta $(\beta)$ konvergenciju. U ovom radu će biti ispitano postojanje oba oblika konvergencije dohodaka. Kao mera dohotka po stanovniku korišćen je BDP per capita korigovan paritetom kupovne moći valute. Izvor podataka je baza podataka World Economic Outlook (2015).

Dohodovna sigma konvergencija postoji ukoliko se razlike u nivou dohotka po stanovniku u određenoj 
grupi zemalja vremenom smanjuju (Barro \& Sala-iMartin, 2003). U ovom radu će se kao mera disperzije nivoa razvijenosti među posmatranim zemljama koristiti koeficijent varijacije realnog BDP per capita (merenog paritetom kupovne moći):

$$
\begin{aligned}
& C V(B D P p c)=\text { standardna devijacija }(B D P p c) / \text { aritmetička } \\
& \text { sredina }(B D P p c)
\end{aligned}
$$

Dohodovna konvergencija u određenoj grupi zemalja postoji ukoliko postoji trend smanjenja koeficijenta varijacije BDP per capita tokom vremena.

Drugi pojavni oblik konvergencije, beta konvergencija, postoji ukoliko manje razvijene ekonomije rastu brže od razvijenih, tj. kada postoji negativna korelacija između inicijalnog nivoa dohotka po stanoviniku i stope ekonomskog rasta $u$ određenom vremenskom intervalu. U svrhu dokazivanja beta konvergencije, testirana je sledeća regresiona jednačina na uzorku zemalja Zapadnog Balkana i novih članica EU:

growth $_{i, t}=\beta_{0}+\beta_{1}$ dist $_{i, t-1}+\beta_{2}$ dist $_{i, t-1} \times W B S+\beta_{3} W B S+u_{i t}$

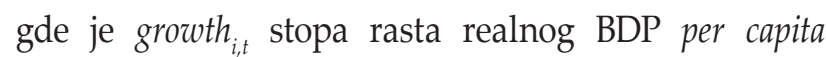
(merenog paritetom kupovnih snaga) zemlje $\mathrm{i} u$ periodu $t$; dist ${ }_{i, t-1}$ jaz u realnom BDP per capita između zemlje i proseka EU15 u prethodnom periodu, a WBS veštačka promenljiva koja uzima vrednost 1 za zemlje koje pripadaju regionu Zapadnog Balkana, a 0 za zemlje koje pripadaju grupi NMS.

Deskriptivna statistika varijabli growth i dist.(distance) prikazana je u Tabeli 1. Sve posmatrane varijable imaju normalnu raspodelu (testirano ShapiroWilk testom). Takođe, ispunjena je i pretpostavka o linearnoj zavisnosti varijabli, dok je testiranjem nakon sprovedene regresije utvrđeno da ne postoje problemi multikolinearnosti (VIF < 10), autokorelacije (DurbinWatson test) i heteroskedastičnosti (Breusch-Pagan / Cook-Weisberg test).

$\mathrm{U}$ navedenom modelu se, pored ispitivanja postojanja konvergencije, ispituje i da li, i u kojoj meri je, eventualna konvergencija grupe WBS različita po brzini u odnosu na konvergenciju grupe NMS, tj. da li pripadnost grupi WBS moderira (tj. menja) uticaj koji dohodovni jaz ima na stopu ekonomskog rasta BDP per capita. Zbog toga je u model uneta i nova nezavisna varijabla - proizvod dist ${ }_{\mathrm{i},-1}$ i veštačke promenljive WBS.
Tabela 1 Deskriptivna statistika promenljivih

\begin{tabular}{l|lllll}
\hline & $\begin{array}{l}\text { Br. } \\
\text { opservacija }\end{array}$ & $\begin{array}{l}\text { Arit. } \\
\text { sredina }\end{array}$ & $\begin{array}{l}\text { St. } \\
\text { devijacija }\end{array}$ & Min. & Max. \\
\hline Growth & 352 & 0,557 & 0,487 & $-0,238$ & 0,212 \\
Distance & 352 & 0,611 & 0,148 & 0,286 & 0,887 \\
\hline
\end{tabular}

Izvor: Autor

Pozitivna vrednost koeficijenta $\beta_{1}$ znači da postoji konvergencija dohodaka posmatranih zemalja (WBS i NMS) i EU15, tj. da je stopa rasta realnog dohotka veća ukoliko je jaz u razvijenosti između posmatrane zemlje i proseka EU15 veći. Što je koeficijent $\beta_{1}$ veći, konvergencija je brža.

Ukoliko je vrednost koeficijenta $\beta_{2^{\prime}}$ koji meri interakciju pripadnosti regionu Zapadnog Balkana i dohodovnog jaza, statistički značajna, pripadnost grupi WBS moderira jačinu uticaja koji dohodovni jaz ima na stopu rasta dohotka po stanovniku. Pozitivna vrednost ovog koeficijenta ukazuje da je brzina konvergencije zemalja WBS veća u odnosu na brzinu konvergencije zemalja NBS. Obrnuto važi za negativan koeficijent $\beta_{2}$.

Koeficijent $\beta_{3}$ određuje $u$ kojoj se meri stope ekonomskog rasta zemalja grupe WBS razlikuju od onih ostvarenih $u$ grupi zemalja NMS. Negativna vrednost ovog koeficijenta ukazuje da su, pri istom inicijalnom dohodovnom jazu sa zemljama EU15, ostvarene niže stope rasta realnog BDP per capita $\mathrm{u}$ grupi WBS nego u grupi NMS, što, takođe, ukazuje na sporiju konvergenciju. Obrnuto je u slučaju pozitivne vrednosti koeficijenta $\beta_{3}$.

\section{REZULTATI}

Prosečan nivo BDP per capita u zemljama NMS je na početku tranzicije bio oko $38 \%$, a u zemljama Zapadnog Balkana svega oko 22\% nivoa ostvarenog u EU15 (Slika 4). Sve do početka XXI-og veka, tranzicija nije dovela do značajnijeg porasta dohotka $\mathrm{u}$ odnosu na zemlje EU. Od 2000, međutim, dolazi do značajnije dohodovne konvergencije. Do 2008, prosečan BDP per capita je u grupi zemalja NMS dostigao $53 \%$, a u grupi WBS 30\% proseka grupe EU15. 
Izbijanje Globalne ekonomske krize zaustavilo je proces sustizanja prosečnog BDP per capita EU15 u tranzicionim zemljama, u grupi zemalja NMS samo na kraći, a u grupi WBS na duži period. Naime, već 2011, BDP per capita je (u odnosu na EU15) u zemljama NMS premašio pretkrizni nivo, te nastavio da raste dostižući 58\% u 2015. S druge strane, od 2008. do 2015, BDP per capita $\mathrm{u}$ odnosu na EU15 je u grupi zemalja Zapadnog Balkana povećan za svega jedan procentni poen $(31 \% \mathrm{u}$ 2015.). Nakon izbijanja Globalne ekonomske krize došlo je do zaustavljanja konvergencije dohodaka među zemljama WBS i EU15, dok je konvergencija dohodaka zemalja NMS i EU15 nastavljena. Istovremeno, povećan je dohodovni jaz između grupa WBS i NMS.

Rezultati konvergencije ostvarenog BDP per capita, upotrebom koncepta sigma dohodovne konvergencije, prikazani su na Slici 5. Disperzija dohodaka (merena koeficijentom varijacije) u grupi zemalja EU15+WBS se tokom posmatranog perioda uglavnom smanjivala, pogotovo u periodu nakon 2000, do izbijanja ekonomske krize. Nakon 2009. dolazi do zaokreta $\mathrm{u}$ trendu, te se disperzija ostvarenih BDP per capita povećava sve do kraja posmatranog perioda. U grupi zemalja NMS+EU15, opadanje disperzije dohodaka je tokom prve decenije XXI-og veka bilo još izraženije, uz kratak prekid 2009. i 2010, nakon čega se beleži dalji njen pad.

Testiranje $\beta$-konvergencije regresionom jednačinom (2) izvršeno je za celokupni posmatrani period (model
4), kao i za tri potperioda: 1993-2000 (model 1), 20012008 (model 2) i 2009-2015 (model 3). Rezultati su dati u Tabeli 2. Statistička valjanost modela meri se koeficijentom determinacije $\mathrm{R}^{2}$ (koji pokazuje procenat objašnjenog varijabiliteta zavisne varijable), kao i njegovom statističkom značajnošću (Prob predstavlja rizik greške da koeficijent determinacije nije značajan; vrednost manja od 0,05 ukazuje na statistički značajan koeficijent determinacije). Rezultati ukazuju da možemo odbaciti postavljen model 3 (2009-2015) kao statistički nepouzdan.

Vrednost koeficijenta uz dist $t_{\mathrm{i}-\mathrm{l}}$ je $\mathrm{u}$ svim slučajevima pozitivna, tj. što je veći jaz $u$ razvijenosti između zemalja grupa NMS i WBS, s jedne, i proseka EU15, s druge strane, stope ostvarenog rasta BDP per capita (PPP) su veće. Ipak, vrednost ovog koeficijenta, kojim se dokazuje postojanje konvergencije dohodaka, statistički je značajna $(p<0.05)$ samo u modelima 2 i 4, tj. za celokupni posmatrani period (1993-2015) i za potperiod 2001-2008. U prvoj deceniji tranzicije (tačnije, u posmatranom potperiodu 1993-2000) i nakon izbijanja Globlne ekonomske krize do danas (u potperiodu 2009-2015), koeficijent nije statistički značajan, tj. konvergencija dohodaka zemalja NMS i WBS, s jedne, i EU15, s druge strane, nije dokazana.

Koeficijent uz varijablu dist $t_{i, t-1} \times$ WBS pokazuje u kojoj meri pripadnost zemlje regionu WBS moderira, tj. menja jačinu veze koja postoji između dohodovnog

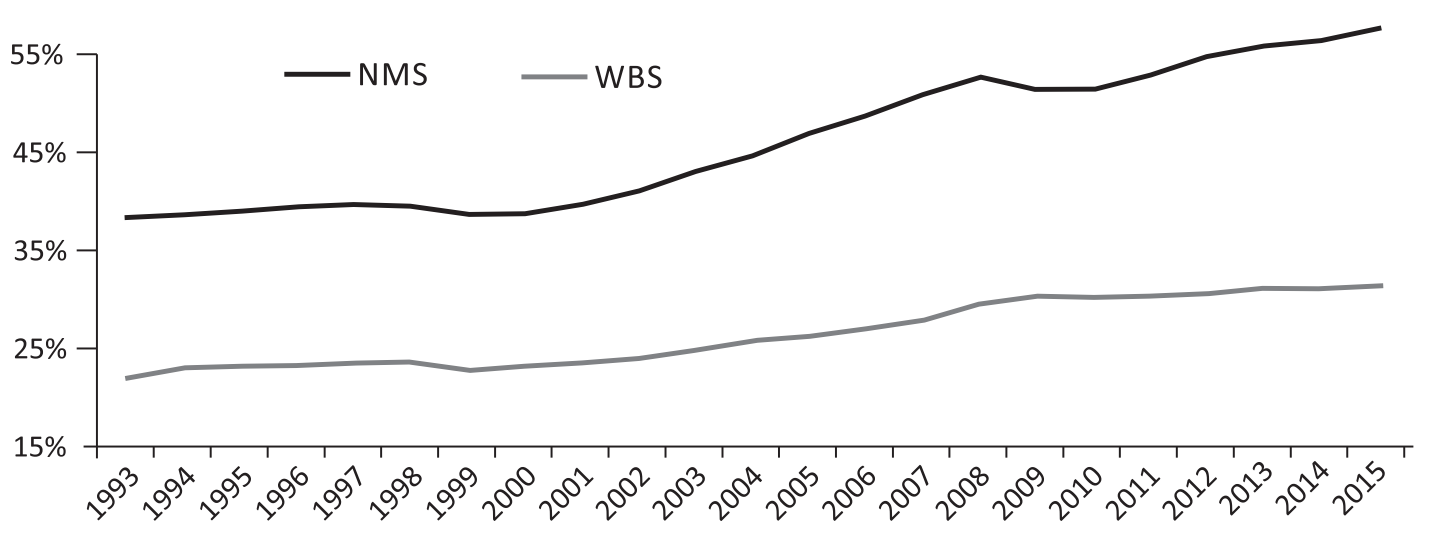

Slika 4 Kretanje BDP per capita (merenog paritetom kupovne moći) u NMS i WBS, u procentima od EU15 


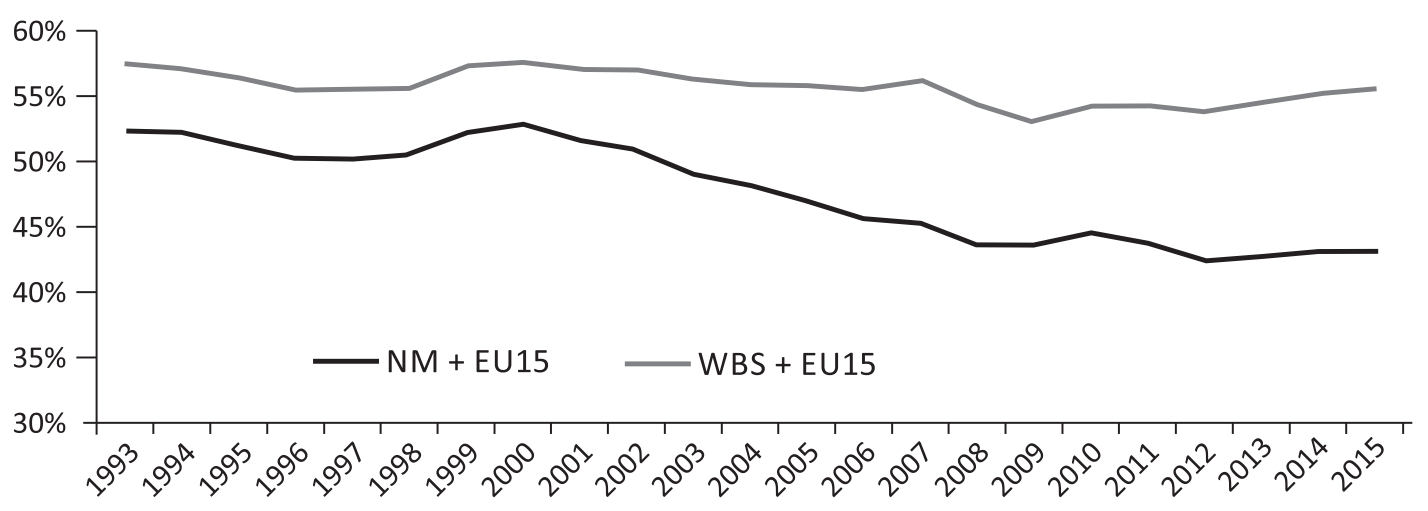

Slika 5 Disperzija BDP per capita u grupama zemalja (merena koeficijentom varijacije).

Izvor: Autor

jaza i ostvarenih stopa rasta BDP per capita. Pozitivna vrednost ovog koeficijenta bi ukazivala da je rast zemalja iz grupe WBS, pri istom nivou dohodovnog jaza, bio brži nego u grupi NMS. Međutim, u svim ispitivanim modelima ovaj koeficijent nije statistički značajan $(p>0.1)$, te zaključujemo da odnos između dohodovnog jaza i rasta BDP per capita nije bio moderiran pripadnošću zemlje regionu Zapadnog Balkana. Ovo, ipak, ne znači da je brzina konvergencije u grupama NMS i WBS bila jednaka. Pre donošenja konačnog zaključka, potrebno je pogledati vrednost koeficijenta uz veštačku promenljivu WBS.
Negativna vrednost koeficijenta uz promenljivu kojom se određuje pripadnost zemlje regionu WBS u svim postavljenim modelima ukazuje da je, pri istom nivou dohodovnog jaza, brzina rasta BDP per capita (PPP) bila veća za zemlje grupe NMS nego za zemlje Zapadnog Balkana. Drugim rečima, sustizanje prosečnog BDP per capita ostvarenog u EU15 je bilo brže u slučaju zemalja NMS nego u slučaju zemalja WBS. Koeficijent je statistički značajan u modelu $1(p<0.1)$ i modelima 2 i 4 ( $p<0.05)$, tj. u potperiodima 1993-2000, 2001-2008 i celokupnom posmatranom periodu 1993-2015.

Tabela 2 Rezultati regresione analize

\begin{tabular}{|c|c|c|c|c|c|c|c|c|}
\hline & \multicolumn{2}{|c|}{$\begin{array}{c}\text { Model } 1 \\
1993-2000\end{array}$} & \multicolumn{2}{|c|}{$\begin{array}{c}\text { Model } 2 \\
2001-2008\end{array}$} & \multicolumn{2}{|c|}{$\begin{array}{c}\text { Model } 3 \\
2009-2015\end{array}$} & \multicolumn{2}{|c|}{$\begin{array}{c}\text { Model } 4 \\
1993-2015\end{array}$} \\
\hline & Coef. & P. & Coef. & P. & Coef. & P. & Coef. & P. \\
\hline $\operatorname{dist}_{i, t-1}$ & .0015 & 0.178 & .1019 & 0.001 & .0582 & 0.267 & .0099 & 0.000 \\
\hline $\operatorname{dist}_{\mathrm{i}, \mathrm{t}-1} \times \mathrm{WBS}$ & .1876 & 0.179 & .0797 & 0.143 & .0746 & 0.406 & .0549 & 0.264 \\
\hline WBS & -.1340 & 0.085 & -.0295 & 0.036 & -.0681 & 0.228 & -.0014 & 0.042 \\
\hline const. & .0541 & 0.131 & .0292 & 0.087 & -.0003 & 0.989 & .0026 & 0.856 \\
\hline$N$ & \multicolumn{2}{|c|}{112} & \multicolumn{2}{|c|}{128} & \multicolumn{2}{|c|}{112} & \multicolumn{2}{|c|}{352} \\
\hline$R^{2}$ & \multicolumn{2}{|c|}{0.246} & \multicolumn{2}{|c|}{0.307} & \multicolumn{2}{|c|}{0.041} & \multicolumn{2}{|c|}{0,268} \\
\hline Prob. & \multicolumn{2}{|c|}{0.000} & \multicolumn{2}{|c|}{0.002} & \multicolumn{2}{|c|}{0.200} & \multicolumn{2}{|c|}{0.000} \\
\hline
\end{tabular}


Rezultati regresione analize sugerišu da je dohovodna konvergencija dokazana za grupe NMS i WBS u periodu 1993-2015, kao i da je ona bila brža u slučaju zemalja NMS.

\section{ZAKLJUČAK}

Sustizanje životnog standarda razvijenih ekonomija Evrope bilo je osnovno očekivanje građana tranzicionih zemalja od procesa tranzicije i pridruživanja Evropskoj uniji. Teza o konvergenciji dohodaka razvijena $u$ okviru neoklasične teorije ekonomskog rasta ide $u$ prilog takvim očekivanjima.

Dvadesetpet godina nakon otpočinjanja tranzicije, možemo konstatovati da su rezultati u pogledu ostvarene dohodovne konvergencije različiti među zemljama. Dok su tranzicione zemlje Centralne Evrope i Baltičkog regiona značajno povećale BDP per capita (i u međuvremenu postale članice Evropske unije), tranzicione reforme i rezultati u zemljama Zapadnog Balkana su, uglavnom, razočaravajući. Ukazivanje na postignute rezultate $\mathrm{u}$ sustizanju dohotka EU15 i poređenje postignutih rezultata zemalja regiona Zapadnog Balkana (WBS) i tranzicionih zemalja koje su tokom prve decenije XXI-og veka ušle u sastav EU, tzv. „novih članica EU“ (NMS) bio je osnovni motiv ovog rada.

Iako je dohodovna konvergencija čest predmet empirijskih istraživanja sprovedenih na primeru novih članica EU, broj radova o konvergenciji dohodaka po stanovniku ostvarenih u zemljama Zapadnog Balkana i EU15 je jako mali, iz čega proizilazi osnovni doprinos ovog rada postojećoj naučnoj literaturi. Naučni doprinos rada proističe i iz činjenice da istraživanja koja upoređuju performanse zemalja Zapadnog Balkana i NMS u pogledu sustizanja prosečnog dohotka EU15 skoro i ne postoje. Takođe, radom je obuhvaćen duži vremenski period (1993-2015), koji uključuje i godine ekonomske krize i postkriznog oporavka, čime je komparacija dveju posmatranih grupa (NMS i WBS), kao i slika o dugoročnoj održivosti procesa konvergencije, potpunija.

Sve do početka ovog veka, tranzicija nije dovela do smanjenja dohodovnog jaza između tranzicionih zemalja i EU. Tek od 2000, dolazi do značajnijeg sustizanja dohotka EU15, kako u grupi NMS, tako i u zemljama WBS. Izbijanje svetske ekonomske krize je zaustavilo dohodovnu konvergenciju, ali u zemljama NMS samo na kratko, a u zemljama WBS na duži period. Kao rezultat toga, nakon izbijanja svetske ekonomske krize dolazi do rasta dohodovnog jaza između grupa zemalja NMS i WBS.

Testiranje sigma koncepta dohodovne konvergencije ukazuje na postojanje konvergencije dohodaka zemalja WBS i EU15 nakon 2000. godine, sve do izbijanja Globalne ekonomske krize, nakon koje dolazi do divergencije. Konvergencija ostvarenog dohotka po stanovniku u grupi zemalja NMS i EU15 je do izbijanja krize bila još brža, da bi se, nakon kraćeg prekida, nastavila od 2011. Navedeni rezultati potvrđuju prvu postavljenu naučnu hipotezu o konvergenciji dohodaka po stanovniku u zemljama Zapadnog Balkana i EU15 u periodu od 2000. godine do izbijanja Globalne ekonomske krize.

Rezultati sprovedene regresione analize dokazuju postojanje dohodovne konvergencije ( $\beta$ koncept) za obe grupe zemalja (NMS i WBS), s jedne strane, i EU15, s druge strane, u periodu 1993-2015, pri čemu je brzina konvergencije bila veća za grupu zemalja NMS. Isti zaključak važi i za period 2000-2008, dok se u periodima 1993-2000. i 2009-2015. ne može utvrditi postojanje $\beta$ konvergencije. Time se druga postavljena hipoteza o jednakosti brzine sustizanja prosečnog BDP per capita EU15 između zemalja Zapadnog Balkana i novih članica EU može odbaciti.

Godine Globalne ekonomske krize zbacile su masku sa solidnog ekonomskog rasta iz pretkriznog periodu u regionu Zapadnog Balkana i otkrile sve nedostatke postojećeg ekonomskog uređenja, (ne)sprovedenih reformi i modela privrednog rasta baziranog uglavnom na rastu domaće tražnje. Tek je nakon izbijanja Krize postalo očigledno da se tranzicija u regionu Zapadnog Balkana razlikuje po rezultatima od one u zemljama NMS.

Sprovedeno istraživanje otvara mnogo pravaca za dalja istraživanja. Pre svega, trebalo bi identifikovati ključne faktore koji su doveli do značajno različitih rezultata tranzicije u grupama NMS i WBS. Takođe, uspeh jedne 
ekonomije bi trebalo da se procenjuje po tome šta se dešava sa životnim standardom većine građana tokom dužeg perioda, a ne po prosečnom ostvarenom BDP per capita. U tom smislu, za ekonomiju se ne može reći da funkcioniše dobro, iako je ostvareno povećanje BDP per capita, ako je došlo do rasta nejednakosti u raspodeli dohotka unutar zemlje (Lekovic, 2015). U tom smislu, rezultati dohodovne konvergencije bi se mogli dopuniti sagledavanjem stepena unutrašnjih dohodovnih nejednakosti tokom tranzicionog perioda.

\section{REFERENCE}

Barro, R. J., \& Sala-i-Martin, X. (2003). Economic Growth. Cambridge: MIT Press.

Cavenaile, L., \& Dubois, D. (2011). An empirical analysis of income convergencein the EuropeanUnion. AppliedEconomics Letters, 18(17), 1705-1708. doi: 10.1080/13504851.2011.560104

Gligorić, M. (2014). Paths of income convergence between country pairs within Europe. Economic Annals, 59(201), 123156. doi:10.2298/eka1401123g

Jakopin, E. (2012). Post-crisis reallocation of growth factors. Economic Horizons, 14(2), 79-90. doi:10.5937/ekonhor1202077J

Kutan, A. M., \& Yigit, T. M. (2004). Nominal and real stochastic convergence of transition economies. Journal of Comparative Economics, 32(1), 23-36. doi: 10.1016/j.jce.2003.09.008

Kutan, A. M., \& Yigit, T. M. (2005). Real and nominal stochastic convergence: Are the new EU members ready to join the Euro zone? Journal of Comparative Economics, 33(2), 387-400. doi:10.1016/j.jce.2005.03.001

Lekovic, V. (2015). Determinants of economic (in)equality and its implications for sustainable economic development. Economic Horizons, 17(2), 79-94. doi: 10.5937/ekonhor1502081L

Mankiw, N. G., Romer, D., \& Weil, D. N. (1992). A contribution to the empirics of economic growth. The Quarterly Journal of Economics, 107(2), 407-437. doi: 10.2307/2118477

Matkowski, Z., \& Prochniak, M. (2004). Real economic convergence in the EU accession countries. International Journal of Applied Econometrics and Quantitative Studies, 1(3), 5-38.

Matkowski, Z., \& Prochniak, M. (2006). Convergence of the economic growth of accession countries in relation to the European Union. In D. Rosati (Ed.). New Europe. Report on Transformation (pp. 169-180). Warsaw: Institute for Eastern
Studies.

Matkowski, Z., \& Prochniak, M. (2007). Economic convergence between the CEE-8 and the European Union. Eastern European Economics, 45(1), 59-76. doi: 10.2753/EEE00128775450103

Murgasova, Z., Ilahi, N., Miniane, J., Scott, A., \& VladkovaHollar, I. (2015). The Western Balkans: 15 years of economic transition. Washington DC: International Monetary Fund.

Prascevic, A. (2013). Achievements of economic policy in overcoming the effects of the global economic crisis on Serbian Economy. Economic Horizons, 15(1), 19-32. doi:10.5937/ ekonhor1301017P

Prochniak, M. (2008). Real economic convergence between Central and Eastern Europe and the European Union. Paper presented at the conference China's Three Decades of Economic Reforms, Chinese Economic association and Cambridge University.

Solow, R. (1956). A contribution to the theory of economic growth. Quarterly Journal of Economics, 70(1), 65-94. doi: $10.2307 / 1884513$

Stanisic, N. (2012). The effects of the economic crisis on income convergence in the European Union. Acta Oeconomica, 62(2), 161-182, doi: 10.1556/AOecon.62.2012.2.2

Tsanana, E., Katrakilidis, C., \& Pantelidis, P. (2012). Balkan area and EU-15: An empirical investigation of income convergence. In A. Karasavvoglou, \& P. Polychronidou (Eds.). Balkan and Eastern European Countries in the Midst of the Global Economic Crisis, Contributions to Economics, Berlin Heidelberg: Springer-Verlag, doi: 10.1007/978-3-7908-2873$3 \_2$

Vamvakidis, A. (2008). Convergence in emerging Europe: Sustainability and Vulnerabilities. IMF Working Paper WP/08/181, Washington DC: International Monetary Fund

Varblane U., \& Vahter, P. (2005). An analysis of the Economic Convergence process in the Transition Countries. University of Tartu-Faculty of Economics \& Business Administration Working Paper Series, 37

Vojinovic, B., \& Oplotnik, Z. (2008). Real convergence in the new EU member states. Praque Economic Papers, 17(1), 23-39. doi: $10.18267 / j . p e p .317$

Vojinovic, B., Acharya, S., \& Prochniak, M. (2009). Convergence analysis among the ten European transition economies. Hitotsubashi Journal of Economics, 50(2), 123-141.

World Economic Outlook. (2015). Washington DC: International Monetary Fond 
Primljeno 8. marta 2016,

nakon revizije,

prihvaćeno za publikovanje 14. aprila 2016.

Elektronska verzija objavljena 25. aprila 2016.

Nenad Stanišić je vanredni profesor na Ekonomskom fakultetu Univerziteta u Kragujevcu. Doktorirao je na Ekonomskom fakultetu Univerziteta u Beogradu iz oblasti međunarodne ekonomije. Ključne oblasti njegovog naučnoistraživačkog interesovanja su međunarodni ekonomski odnosi, međunarodna trgovina i finansije, i međunarodna ekonomska integracija.

\title{
INCOME CONVERGENCE IN THE PROCESS OF THE WESTERN BALKAN STATES' ACCESSION TO THE EUROPEAN UNION
}

\author{
Nenad Stanisic \\ Faculty of Economics, University of Kragujevac, Kragujevac, The Republic of Serbia
}

One of the main expectations in European transition economies is that the processes of building the market economy and European integrations lead to a significant increase in the living standard, as well as to catching up with the level of the income per capita achieved in developed European economies. A quarter century after the beginning of transition, many of the former socialist countries joined the EU and significantly increased their GDP per capita. On the other hand, transition in the countries of the so-called Western Balkans has disappointed in this sense. The paper tests the existence and speed of income convergence in the Western Balkan states and developed EU countries, in comparison with the so-called „New Member States”. The results indicate that, despite the achieved income convergence in the pre-crisis years, the outbreak of the global economic crisis has revealed many structural and reform problems that the countries of the region have been facing for a long time. Catching up with developed EU members' average GDP per capita stopped in the Western Balkan states after the beginning of the crisis, with a simultaneous increase in the income gap between the Western Balkan states and the new EU member states.

Keywords: income convergence, economic development, the Western Balkans economies, European economic integrations 